\title{
Diurnal variations of organic molecular tracers and stable carbon isotopic composition in atmospheric aerosols over Mt. Tai in the North China Plain: an influence of biomass burning
}

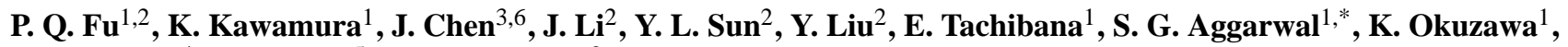 \\ H. Tanimoto ${ }^{4}$, Y. Kanaya ${ }^{5}$, and Z. F. Wang ${ }^{2}$ \\ ${ }^{1}$ Institute of Low Temperature Science, Hokkaido University, Sapporo 060-0819, Japan \\ ${ }^{2}$ State Key Laboratory of Atmospheric Boundary Layer Physics and Atmospheric Chemistry, \\ Institute of Atmospheric Physics, Chinese Academy of Sciences, Beijing 100029, China \\ ${ }^{3}$ SKLEG, Institute of Geochemistry, Chinese Academy of Sciences, Guiyang 550002, China \\ ${ }^{4}$ National Institute for Environmental Studies, Tsukuba, Japan \\ ${ }^{5}$ Frontier Research Center for Global Change, Japan Agency for Marine-Earth Science and Technology, Kanagawa, Japan \\ ${ }^{6}$ Graduate School of the Chinese Academy of Sciences, Beijing 100049, China \\ *now at: National Physical Laboratory, New Delhi 110012, India
}

Correspondence to: P. Q. Fu (fupingqing@mail.iap.ac.cn) and K. Kawamura (kawamura@lowtem.hokudai.ac.jp)

Received: 25 March 2012 - Published in Atmos. Chem. Phys. Discuss.: 10 April 2012

Revised: 27 August 2012 - Accepted: 1 September 2012 - Published: 18 September 2012

\begin{abstract}
Organic tracer compounds, as well as organic carbon (OC), elemental carbon (EC), water-soluble organic carbon (WSOC), and stable carbon isotope ratios $\left(\delta^{13} \mathrm{C}\right)$ of total carbon (TC) have been investigated in aerosol samples collected during early and late periods of the Mount Tai eXperiment 2006 (MTX2006) field campaign in the North China Plain. Total solvent-extractable fractions were investigated by gas chromatography/mass spectrometry. More than 130 organic compounds were detected in the aerosol samples. They were grouped into twelve organic compound classes, including biomass burning tracers, biogenic primary sugars, biogenic secondary organic aerosol (SOA) tracers, and anthropogenic tracers such as phthalates, hopanes and polycyclic aromatic hydrocarbons (PAHs). In early June when the field burning activities of wheat straws in the North China Plain were very active, the total identified organics $\left(2090 \pm 1170 \mathrm{ng} \mathrm{m}^{-3}\right)$ were double those in late June $\left(926 \pm 574 \mathrm{ng} \mathrm{m}^{-3}\right)$. All the compound classes were more abundant in early June than in late June, except phthalate esters, which were higher in late June. Levoglucosan (88$1210 \mathrm{ng} \mathrm{m}^{-3}$, mean $403 \mathrm{ng} \mathrm{m}^{-3}$ ) was found as the most abundant single compound in early June, while diisobutyl phthalate was the predominant species in late June. During
\end{abstract}

the biomass-burning period in early June, the diurnal trends of most of the primary and secondary organic aerosol tracers were characterized by the concentration peaks observed at mid-night or in early morning, while in late June most of the organic species peaked in late afternoon. This suggests that smoke plumes from biomass burning can uplift the aerosol particulate matter to a certain altitude, which could be further transported to and encountered the summit of Mt. Tai during nighttime. On the basis of the tracer-based method for the estimation of biomass-burning $\mathrm{OC}$, fungalspore $\mathrm{OC}$ and biogenic secondary organic carbon (SOC), we estimate that an average of $24 \%$ (up to $64 \%$ ) of the OC in the Mt. Tai aerosols was due to biomass burning in early June, followed by the contribution of isoprene SOC (mean $4.3 \%)$. In contrast, isoprene SOC was the main contributor $(6.6 \%)$ to $\mathrm{OC}$, and only $3.0 \%$ of the $\mathrm{OC}$ was due to biomass burning in late June. In early June, $\delta^{13} \mathrm{C}$ of TC (-26.6 to $-23.2 \%$, mean $-25.0 \%$ ) were lower than those $(-23.9$ to $-21.9 \%$, mean $-22.9 \%$ ) in late June. In addition, a strong anti-correlation was found between levoglucosan and $\delta^{13} \mathrm{C}$ values. This study demonstrates that crop-residue burning activities can significantly enhance the organic aerosol loading and alter the organic composition and stable carbon isotopic 
composition of aerosol particles in the troposphere over the North China Plain.

\section{Introduction}

Organic aerosols are essential components in the Earth's atmosphere (de Gouw and Jimenez, 2009). They play major roles in the environmental issues related to global and regional climate, chemistry of the atmosphere, biogeochemical cycling, and people's health (Andreae and Crutzen, 1997; Kanakidou et al., 2005; Pöschl, 2005). In order to better evaluate their potential impacts, it is necessary to fully understand the sources and molecular composition of organic aerosols. Generally, organic aerosols are comprised of primary (POA) and secondary organic aerosol (SOA). The oxidation of biogenic volatile organic compounds (VOCs) emitted by vegetation, such as isoprene, monoterpenes, and sesquiterpenes importantly contributes to the total atmospheric burden of SOA (de Gouw and Jimenez, 2009). Andreae and Crutzen (1997) estimated that the global SOA formation (30-270 $\left.\mathrm{Tg} \mathrm{yr}^{-1}\right)$ is comparable to that of secondary sulfate aerosol. A global three-dimensional chemistry/transport model study indicates that under certain circumstances SOA can be the main fraction of organic aerosols (Tsigaridis and Kanakidou, 2003).

The Asian continent is an important source region of atmospheric aerosols with various origins including biomass burning, dust storms, and industrial and residential emissions (Streets et al., 2003; Zheng et al., 2005; Zhang et al., 2012). The outflow of Asian continental pollutants (including the Asian dust) to the East China Sea and western North Pacific has increasingly been recognized, and the long-range atmospheric transport of the Asian dust has also been identified in several events backed up by model analysis (Uno et al., 2001). The North China Plain (NCP) is regarded as one of the most significant aerosol source regions in the world (Andreae and Rosenfeld, 2008). In NCP, the field burning of agricultural residues (mainly wheat straws) is a common way to eliminate the wastes after harvesting in early summer ( $\mathrm{Li}$ et al., 2007). Such biofuel is also one of the major domestic energy sources for cooking and heating in rural areas. It was also reported that the field burning of wheat straw in Hebei Province and Shangdong Province caused serious air pollution in Beijing in June, 2006 (Li et al., 2007). We have reported the day/night difference of organic molecular composition and temporal variations of summertime aerosols in the troposphere over Mt. Tai in NCP (Fu et al., 2008), which is located on the transport pathway of the Asian continental outflow when westerly winds prevail. Our chemical characterization revealed several biomass burning pollution episodes that occurred during the Mt. Tai eXperiment 2006 (MTX2006) campaign. Yamaji et al. (2010) have evaluated the influence of open crop residual burning on ozone, $\mathrm{CO}$, black carbon $(\mathrm{BC})$ and organic carbon (OC) concentrations in NCP using a regional chemical transport model during the same campaign.

The objective of this study is to investigate the diurnal variations of both POA and SOA tracers and stable carbon isotopic compositions of total carbon (TC) in the tropospheric aerosols over Mt. Tai. More than 130 organic compounds including aliphatic lipids, sugar compounds, lignin and resin products, aromatic acids, polyacids, sterols, hopanes, polycyclic aromatic hydrocarbons (PAHs), and biogenic oxidation products (e.g., 2-methyltetrols, pinic acid, and $\beta$ caryophyllinic acid) were measured in the aerosol particles. By comparing the results of aerosol samples collected in early and late June when the field burning of wheat straws was active and weak, respectively, we can better understand the influence of biomass burning on the stable carbon isotope ratios and organic molecular composition of tropospheric aerosols at high altitudes in East Asia.

\section{Experimental}

\subsection{Sample collection}

Mt. Tai $\left(36.25^{\circ} \mathrm{N}\right.$ and $117.10^{\circ} \mathrm{E}, 1534 \mathrm{~m}$ a.s.l.) is located in Shandong Province in the North China Plain, which is on the transport path of the Asian continental outflow. It is a tilted fault-block mountain with height increasing from the north to the south, facing to the East China Sea, Korean Peninsula and Japanese Islands. Timeresolved (06:00-09:00, 09:00-12:00, 12:00-15:00, 15:0018:00, 18:00-21:00, 21:00-24:00, 00:00-03:00, and 03:0006:00, local time) aerosol samples (total suspended particles, TSP) were collected using a high-volume air sampler (Kimoto AS-810) on 2-5 June (early June, $n=24$ ) and 23-25 June (late June, $n=13$ ) at the summit of Mt. Tai during the MTX2006 campaign. All the samples were collected onto pre-combusted $\left(450^{\circ} \mathrm{C}\right.$ for $\left.6 \mathrm{~h}\right)$ quartz fiber filters $(20 \mathrm{~cm} \times 25 \mathrm{~cm}$, Pallflex). Before sampling, each filter was placed in a pre-combusted $\left(450^{\circ} \mathrm{C}\right.$ for $\left.6 \mathrm{~h}\right)$ glass jar with a Teflon-lined cap during the transport and storage. After sampling, the filter was returned into the glass jar, and then transported to the laboratory and stored at $-20^{\circ} \mathrm{C}$ in darkness prior to analysis. It should be noted that the sampling artifacts might occur due to the evaporation/adsorption processes of semi-volatile organics on the filter or particle surface during sampling (Turpin et al., 2000).

\subsection{Extraction and derivatization}

Aliquots of the sample and blank filters (ca. $10 \mathrm{~cm}^{2}$ ) were extracted three times for $10 \mathrm{~min}$ each with dichloromethane/methanol $(2: 1 ; v / v)$ under ultrasonication. The solvent extracts were filtered through quartz wool packed in a Pasteur pipette, concentrated by the use of a rotary evaporator, and blown down to dryness with pure 
nitrogen gas. The extracts were then reacted with $50 \mu \mathrm{l}$ of N,O-bis-(trimethylsilyl)trifluoroacetamide (BSTFA) with $1 \%$ trimethylsilyl chloride and $10 \mu \mathrm{l}$ of pyridine at $70^{\circ} \mathrm{C}$ for $3 \mathrm{~h}$. After reaction, the derivatives were diluted by $140 \mu \mathrm{l}$ of $n$-hexane with $1.43 \mathrm{ng}^{-1}$ of the internal standard $\left(\mathrm{C}_{13}\right.$ $n$-alkane) prior to gas chromatography-mass spectrometry (GC-MS) injection.

\subsection{Gas chromatography-mass spectrometry}

GC-MS analyses were performed on a Hewlett-Packard model 6890 GC coupled to a Hewlett-Packard model 5973 mass-selective detector (MSD). The GC was equipped with a split/splitless injection and a DB-5MS fused silica capillary column $(30 \mathrm{~m} \times 0.25 \mathrm{~mm}$ i.d., $0.25 \mu \mathrm{m}$ film thickness $)$ with a GC oven temperature programmed from $50^{\circ} \mathrm{C}(2 \mathrm{~min})$ to $120^{\circ} \mathrm{C}$ at $15^{\circ} \mathrm{C} \mathrm{min}^{-1}$ and then to $300^{\circ} \mathrm{C}$ at $5{ }^{\circ} \mathrm{C} \mathrm{min}^{-1}$ with final isothermal hold at $300^{\circ} \mathrm{C}$ for $16 \mathrm{~min}$. The sample was injected on a splitless mode with the injector temperature at $280^{\circ} \mathrm{C}$. The mass spectrometer was operated in the electron ionization (EI) mode at $70 \mathrm{eV}$ and scanned in the $m / z$ range of 50-650. Data were acquired and processed with the Chemstation software.

GC-MS response factors were determined using authentic standards except for several biogenic SOA tracers. For the quantification of 3-hydroxyglutaric, cis-pinonic and pinic acids that are formed by the oxidation of $\alpha-/ \beta$-pinene, their GC-MS response factors were also determined using authentic standards. Other $\alpha$ - $/ \beta$-pinene SOA tracers including 3-(2-hydroxyethyl)-2,2-dimethylcyclobutane carboxylic acid (HDCCA), 3-acetylglutaric acid, 3-acetyladipic acid, and 3-isopropylglutaric acid were quantified using malic acid. $\beta$-Caryophyllinic acid (a diacid similar to pinic acid) was estimated using the response factor of pinic acid. 2Methylglyceric acid, $\mathrm{C}_{5}$-alkene triols, 2-methyltetrols and 3-methyl-1,2,3-butanetricarboxylic acid were quantitatively determined with a capillary GC (Hewlett-Packard, HP6890) equipped with a split/splitless injector, fused-silica capillary column (HP-5, $25 \mathrm{~m} \times 0.2 \mathrm{~mm}$ i.d., $0.50 \mu \mathrm{m}$ film thickness), and a flame ionization detector (FID). The identification of the organic compounds quantified by GC-FID was confirmed by GC-MS analysis. The standard of meso-erythritol, a surrogate compound generally used for the quantification of 2methyltetrols, was quantitatively determined by both GC-MS and GC-FID. The analytical error in the quantification of meso-erythritol between the two methods was $<5 \%$. The field and the laboratory blank filters were also analyzed by the procedure as same as the aerosol samples; their results showed no significant contamination (less than $5 \%$ of real samples) except for bis(2-ethylhexyl) phthalate, whose field blank levels sometimes were high (up to $60 \%$ of real samples) and thus were not used in this study. More details of the method and recoveries are described elsewhere (Fu et al., 2008, 2010).

\subsection{OC, EC, and WSOC analyses}

Organic carbon (OC) and elemental carbon (EC) were determined using a Sunset Lab carbon analyzer, following the Interagency Monitoring of Protected Visual Environments (IMPROVE) thermal evolution protocol and assuming carbonate carbon in the sample to be negligible. In brief, a $1.54 \mathrm{~cm}^{2}$ punch $(\varnothing 14 \mathrm{~mm}$ ) was cut off from each quartz filter sample. The punched filter was placed in a quartz boat inside the thermal desorption chamber of the analyzer, and then stepwise heating was applied. The analytical errors in triplicate analysis were within $5 \%$ and the detection limits were $0.2 \mu \mathrm{g} \mathrm{cm}^{-2}$ for both OC and EC.

Another aliquot (ca. $3.14 \mathrm{~cm}^{2}$ ) of filter sample was extracted with organic-free Milli-Q water under ultrasonication for $20 \mathrm{~min}$. The water extracts were then passed through a syringe filter (Millex-GV, $0.22 \mu \mathrm{m}$, Millipore), and then analyzed for water-soluble organic carbon (WSOC) using a TOC analyzer (Shimadzu 5000A). The difference between OC and WSOC was considered as water-insoluble OC (WIOC).

\section{$2.5 \quad \delta^{13} \mathrm{C}$ analyses}

The determination of stable carbon isotope ratios $\left(\delta^{13} \mathrm{C}\right)$ of total carbon was conducted using an elemental analyzer (EA) (Carlo Erba, NA 1500) interfaced to an isotope ratio mass spectrometer (irMS) (Finnigan MAT, Delta Plus) (Kawamura et al., 2004). An aliquot of each sample $\left(2.54 \mathrm{~cm}^{2}\right)$ was placed in a tin cup, introduced into EA, and then oxidized in a combustion column that was packed with $\mathrm{CuO}$ at $1020^{\circ} \mathrm{C}$. The water from the samples in the helium gas flow was removed by magnesium perchlorate. The derived gases $\left(\mathrm{CO}_{2}\right.$ and $\mathrm{NO}_{\mathrm{x}}$ ) were introduced into the reduction column to reduce $\mathrm{NO}_{\mathrm{x}}$ to $\mathrm{N}_{2}$ and then isolated on a gas chromatograph installed in the EA system. $\mathrm{CO}_{2}$ and $\mathrm{N}_{2}$ gases were transferred to EA/irMS via an interface (ConFlow II) for isotope ratio measurement. The isotopic compositions $\left(\delta^{13} \mathrm{C}\right)$ of TC relative to Pee Dee Belemnite (PDB) were determined using the standard isotopic conversion: $\delta^{13} \mathrm{C}=\left(R_{\text {sample }} / R_{\text {standard }}-\right.$ $1) \times 1000$, where $R$ is the ratio of ${ }^{13} \mathrm{C} /{ }^{12} \mathrm{C}$. The analytical error based on duplicate analysis in the carbon isotope ratios was within $0.2 \%$.

All the data reported here were corrected for field blanks.

\section{Results and discussion}

\subsection{Fire spots, air mass back trajectories, and meteorological conditions}

Every early summer, mainly in early- to mid-June, the agricultural waste burning after wheat harvest in the Provinces of Anhui, Jiangsu, Shandong, Henan and Hebei in the North China Plain can cause heavy air pollution on a local and regional scale. In this study, the fire spots surrounding Mt. Tai (AVHRR-sensor type dataset) were provided by the 

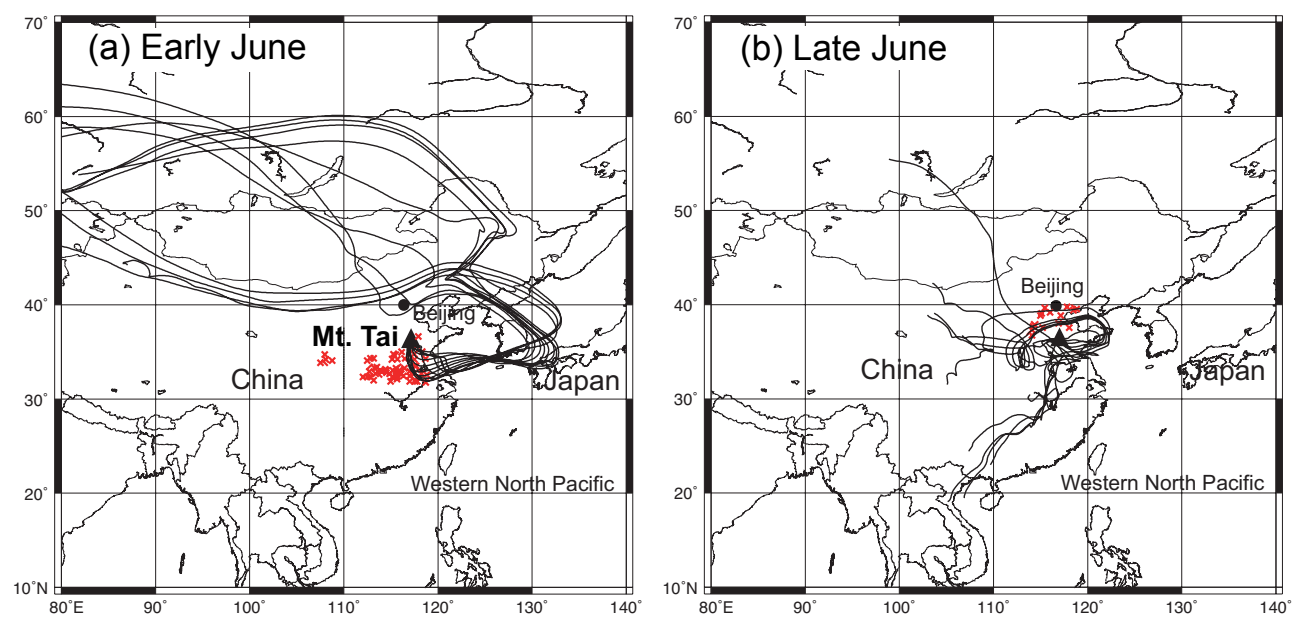

Fig. 1. Ten-day air mass back trajectories arriving at $1500 \mathrm{~m}$ (above sea level) over Mt. Tai during the sampling period of (a) early June (2-5 June) and (b) late June (23-25 June). The solid triangle represents the sampling site of Mt. Tai in Central East China. Fire spot data during (a) 31 May-5 June and (b) 19-25 June that were derived from AVHRR sensor are presented in red.

Chinese remote sensing meteorological satellite (http://www. sepa.gov.cn/hjjc/stjc/index.htm). As seen in Fig. 1, active fire spots located in the south of Mt. Tai in early June, while they moved to the north and faded out in late June. Ten-day air mass back trajectory analysis showed that in early June (Fig. 1a), the air masses mostly came from the northeast or north direction on the way to Central East China and then turned back to Mt. Tai, when the field burning of agricultural waste (wheat straw) was very active in the Provinces of Anhui, Jiangsu, and Shandong. These regions are located in the south of Mt. Tai. In late June (Fig. 1b), the majority of the air masses came directly from South China, while the wheat harvesting areas (fire spots) were only limited in the north of Mt. Tai, and thus the influence of biomass burning to Mt. Tai is minor. Detailed description of the meteorological and chemical conditions during the MTX2006 field campaign can be found in $\mathrm{Li}$ et al. (2008). In brief, $\mathrm{O}_{3}, \mathrm{CO}$, and $\mathrm{NO}_{\mathrm{x}}$ levels were higher in early June than those in late June. The ambient air temperature $\left(15-25^{\circ} \mathrm{C}\right)$ generally increased from early to late June during the campaign.

\subsection{Concentrations of OC, EC, WSOC and WIOC and their diurnal trends}

The results of carbonaceous components are presented in Table 1. OC concentrations of $7.5-44.2 \mu \mathrm{g} \mathrm{m}^{-3}$ (mean $20.9 \mu \mathrm{g} \mathrm{m}^{-3}$ ) in early June were $2-3$ times higher than those in late June $\left(2.0-15.2 \mu \mathrm{g} \mathrm{m}^{-3}\right.$, mean $\left.8.1 \mu \mathrm{g} \mathrm{m}^{-3}\right)$. Similarly, WSOC concentrations in early June $\left(4.6-31.6 \mu \mathrm{g} \mathrm{m}^{-3}\right.$, $13.9 \mu \mathrm{g} \mathrm{m}^{-3}$ ) were $2-3$ times higher than those (1.1$\left.8.5 \mu \mathrm{g} \mathrm{m}^{-3}, 4.5 \mu \mathrm{g} \mathrm{m}^{-3}\right)$ in late June. EC contributed to 8 $21 \%(14 \%)$ and $0-22 \%(14 \%)$ of the particulate carbon (TC) content in early and late June, respectively. EC and WIOC were both higher in early June than late June. WIOC concentrations were $2.6-12.6 \mu \mathrm{g} \mathrm{m}^{-3}\left(7.0 \mu \mathrm{g} \mathrm{m}^{-3}\right)$ in early

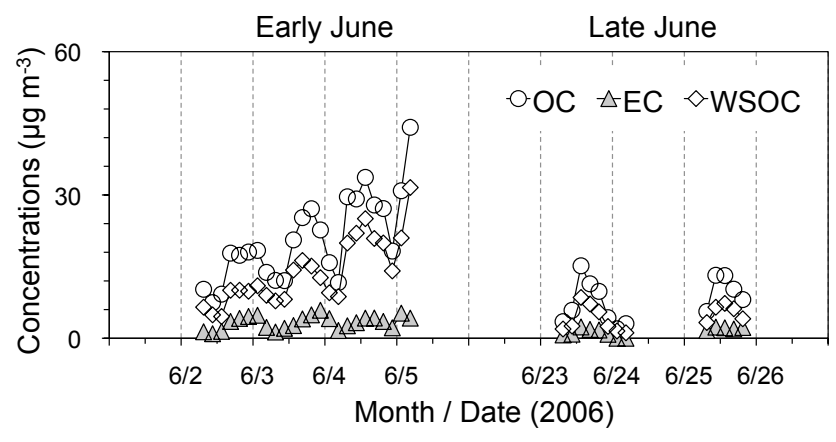

Fig. 2. Diurnal variations of carbonaceous components in the timeresolved (3-h) atmospheric aerosol particles (TSP) over Mt. Tai in June 2006.

June and $0.47-6.7 \mu \mathrm{g} \mathrm{m}^{-3}\left(3.6 \mu \mathrm{g} \mathrm{m}^{-3}\right)$ in late June. Figure 2 shows the diurnal variations of OC, EC and WSOC. Clearly, the concentrations of WSOC are well correlated with those of OC. Although only minor differences in the WSOC/OC ratios were observed between early June $(0.49-0.77)$ and late June $(0.37-0.76)$, the average WSOC/OC ratio was higher in early June (0.65) than in late June (0.55) (Table 1). These results suggest that WSOC constituted an important fraction of OC. In addition, the enhancement of WSOC in OC in early June may be caused by intensified biomass burning, which should be a significant source of water-soluble organics. It is well documented that biomass burning emits a large amount of black carbon. In the present study, EC concentrations in early June $\left(0.95-5.9 \mu \mathrm{g} \mathrm{m}^{-3}, 3.3 \mu \mathrm{g} \mathrm{m}^{-3}\right)$ were double those (nd-2.4 $\mu \mathrm{g} \mathrm{m}^{-3}, 1.4 \mu \mathrm{g} \mathrm{m}^{-3}$ ) in late June. However, similar EC/OC ratios were found between early $(0.09-0.26)$ and late June (0-0.29). Such low values indicate that SOA is an important source of OC in the aerosols over Mt. Tai in summer. 
Table 1. Summary of carbonaceous components and stable carbon isotopic composition in the time-resolved (3-h) aerosol samples (TSP) collected at the summit of Mt. Tai during early (2-5 June) and late (23-25 June) periods of the MTX2006 campaign.

\begin{tabular}{|c|c|c|c|c|c|c|}
\hline \multirow{2}{*}{ Component } & \multicolumn{3}{|c|}{ Early June $(n=24)$} & \multicolumn{3}{|c|}{ Late June $(n=13)$} \\
\hline & range & mean & $\operatorname{std}^{\mathrm{a}}$ & range & mean & std \\
\hline $\mathrm{OC}\left(\mu \mathrm{gC} \mathrm{m} \mathrm{m}^{-3}\right)$ & $7.5-44.2$ & 20.9 & 9.1 & $2.0-15.2$ & 8.1 & 4.4 \\
\hline $\mathrm{EC}\left(\mu \mathrm{gCm} \mathrm{m}^{-3}\right)$ & $0.95-5.9$ & 3.3 & 1.4 & $n d^{b}-2.4$ & 1.4 & 0.86 \\
\hline WSOC $\left(\mu \mathrm{gCm} \mathrm{m}^{-3}\right)$ & $4.6-31.6$ & 13.9 & 6.9 & $1.1-8.5$ & 4.5 & 2.5 \\
\hline WIOC $\left(\mu \mathrm{gC} \mathrm{m}^{-3}\right)$ & $2.6-12.6$ & 7.0 & 2.7 & $0.47-6.7$ & 3.6 & 2.0 \\
\hline $\mathrm{EC} / \mathrm{OC}$ & $0.09-0.26$ & 0.16 & 0.05 & $0-0.29$ & 0.16 & 0.08 \\
\hline WSOC/OC & $0.49-0.77$ & 0.65 & 0.08 & $0.37-0.76$ & 0.55 & 0.09 \\
\hline WIOC/OC & $0.23-0.51$ & 0.35 & 0.08 & $0.24-0.63$ & 0.45 & 0.09 \\
\hline$\delta^{13} \mathrm{C}(\% o)$ & -26.6 to -23.2 & -25.0 & 1.0 & -23.9 to -21.9 & -22.9 & 0.6 \\
\hline
\end{tabular}

${ }^{\mathrm{a}}$ std $=$ standard deviation, ${ }^{\mathrm{b}}$ nd $=$ not detected

\subsection{Organic molecular composition}

More than 130 organic species were detected in the aerosol samples (Supplement Table S1). They were grouped into 12 compound classes based on functional groups and sources. In early June, total concentrations of the measured organics ranged from 610 to $5840 \mathrm{ng} \mathrm{m}^{-3}$ (mean $2090 \mathrm{ng} \mathrm{m}^{-3}$ ); sugar compounds, $n$-alkanes, fatty acids and fatty alcohols were the major compound classes. In late June, total concentrations ranged from 36 to $1990 \mathrm{ng} \mathrm{m}^{-3}\left(926 \mathrm{ng} \mathrm{m}^{-3}\right)$ with the predominance of phthalate esters, followed by biogenic SOA tracers, fatty acids and sugar compounds. Among all the measured organic compound classes, only phthalate esters showed higher levels in late June than in early June (Fig. 3). Figure 4 presents the diurnal variations of the measured 12 organic compound classes. $n$-alkanes, fatty acids, fatty alcohols, lignin and resin products, as well as polyacids showed similar diurnal patterns with much higher concentrations in early June than in late June. These organic species can be emitted abundantly by biomass burning, a point to be discussed later.

\subsubsection{Biomass-burning tracers: enhanced concentrations in early June}

Biomass burning is a significant source of atmospheric gases and particles on a regional to global scale. The biomassburning-derived particles can influence the global climate by absorbing radiation and acting as $\mathrm{CCN}$ (Mochida and Kawamura, 2004). Levoglucosan, produced in large quantities during pyrolysis of cellulose, is a key tracer for biomass burning (Simoneit, 2002). Levoglucosan (88-1210 $\mathrm{ng} \mathrm{m}^{-3}$, $403 \mathrm{ng} \mathrm{m}^{-3}$ ) was found as the most abundant single compound in early June, indicating a significant impact of biomass burning to the aerosols over the summit of Mt. Tai. Strong positive correlations were found between levoglucosan and OC (Supplement Fig. S1a), suggesting that biomass burning was an important source of aerosol OC

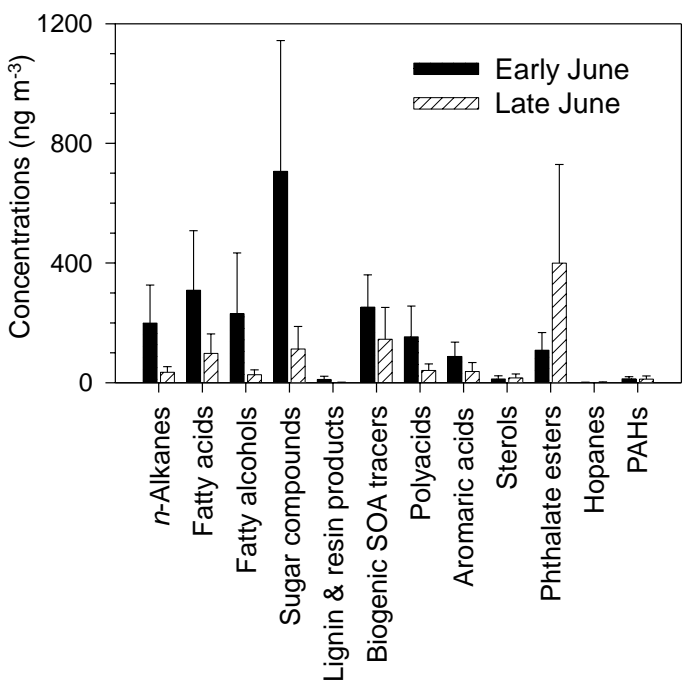

Fig. 3. A comparison of average concentrations of the organic compound classes in early June and late June.

during the sampling period. WSOC is generally produced through photochemical processes. However, in current study, levoglucosan was also highly correlated with WSOC $\left(R^{2}=\right.$ 0.70 , Fig. S1a), indicating a link between WSOC and biomass burning emission (Wang et al., 2011).

Galactosan and mannosan, the isomers of levoglucosan, were also detected in the samples (Table S1). These anhydrosugars are produced by the pyrolysis of cellulose/hemicelluloses during biomass burning (Simoneit, 2002). They have been often identified in smoke particles from woods, grasses, and agricultural wastes (Sheesley et al., 2003; Iinuma et al., 2007). Mean concentrations of levoglucosan, galactosan and mannosan in late June were $25 \mathrm{ng} \mathrm{m}^{-3}$, $1.1 \mathrm{ng} \mathrm{m}^{-3}$ and $0.9 \mathrm{ng} \mathrm{m}^{-3}$, respectively; they were more than 10 times lower than those in early June (Table S1). The levels of anhydrosugars in late June were comparable with those reported in background sites in Europe (Puxbaum et 

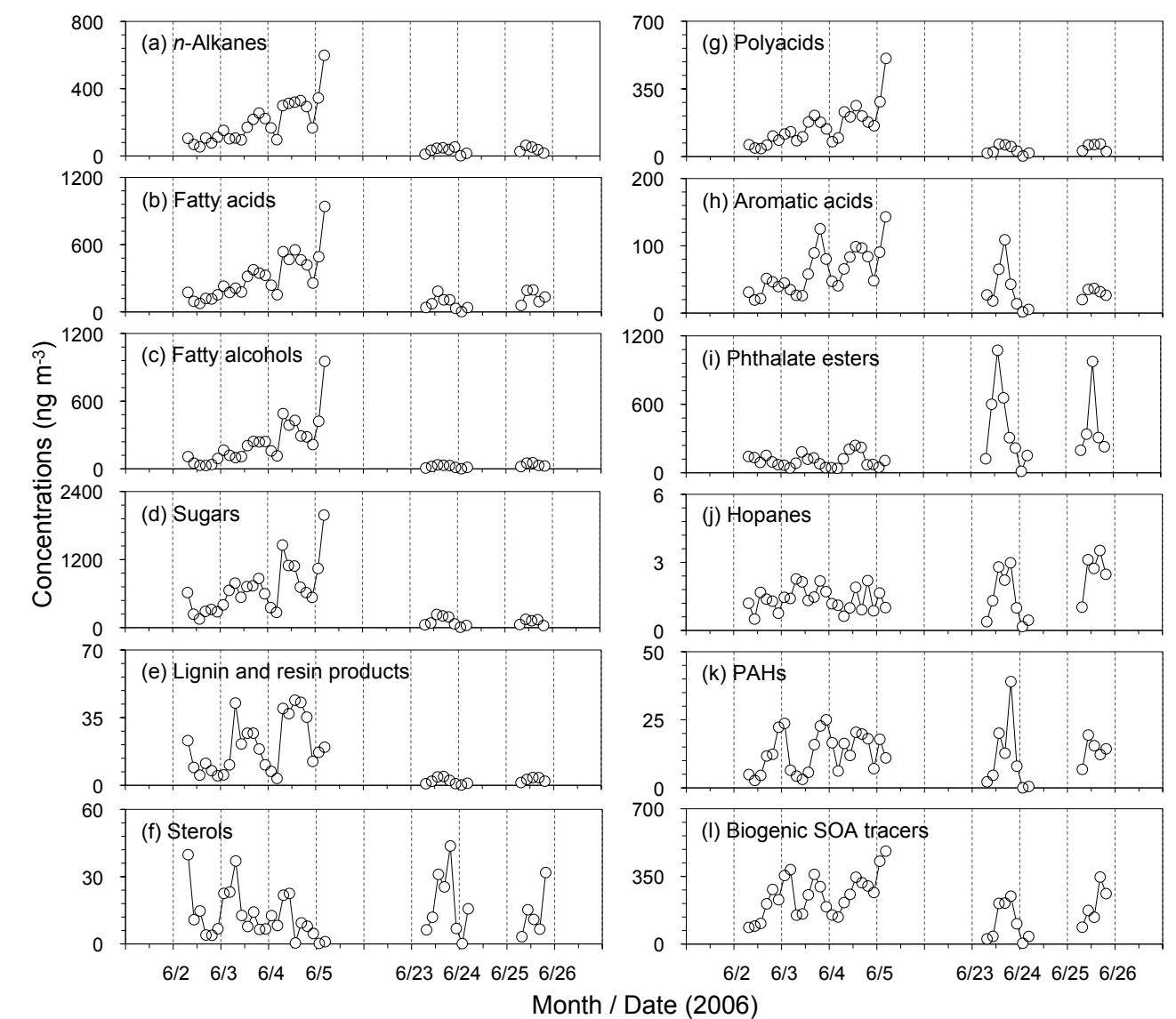

Fig. 4. Diurnal variations of twelve organic compound classes detected in the tropospheric aerosols at the summit of Mt. Tai.

al., 2007) and the marine atmosphere (Simoneit and Elias, 2000).

Fabbri et al. (2008) reported that mannosan was not detected by analytical pyrolysis of lignites, while it was detected at low levels in the smoke of lignites (Fabbri et al., 2009). They suggested mannosan as a more diagnostic marker for recent biomass. Thus, the isomeric ratio of levoglucosan to other anhydrosugars could be used as a more specific tracer for biomass burning. In this study, the mass concentration ratios of levoglucosan to mannosan $(L / M)$ were 26-59 (mean 40) in early June. This may suggest that the field burning of wheat straws is characterized by a higher $L / M$ ratio. In late June, this ratio was much lower, ranging from 2.5 to 48 (mean 25). The higher $L / M$ ratios observed in early June than in late June agree well with those for other types of straw burning smokes (especially rice straw) (Sheesley et al., 2003; Engling et al., 2009), confirming the usefulness of these characteristic ratios as indicators of straw burning.

Dehydroabietic acid, a more specific biomass-burning tracer of conifer resin, was detected at low levels in the Mt. Tai aerosols (early June: $3.4 \pm 4.0 \mathrm{ng} \mathrm{m}^{-3}$; late June: $0.5 \pm 0.4 \mathrm{ng} \mathrm{m}^{-3}$ ), suggesting that fires in the boreal conifer forests are not important during the sampling period (early summer). Lignin is wood polymer and yields phenolic acids upon burning. Vanillic acid is produced from both softwood and hardwood. In contrast, syringic acid is more specific to hardwood, which was found at trace levels. Their total concentrations $\left(1.3-52 \mathrm{ng} \mathrm{m}^{-3}\right.$, mean $\left.11 \mathrm{ng} \mathrm{m}^{-3}\right)$ in early June were 10 times higher than those $\left(0.05-2.0 \mathrm{ng} \mathrm{m}^{-3}\right.$, $1.1 \mathrm{ng} \mathrm{m}^{-3}$ ) in late June. The latter was comparable with those $\left(0.5-9.0 \mathrm{ng} \mathrm{m}^{-3}\right)$ reported in marine aerosols near the Asian continent (Simoneit et al., 2004b).

$\beta$-Sitosterol is a general biomass burning tracer, which is present in all vegetations (Simoneit, 2002). High concentrations of $\beta$-sitosterol were reported in marine aerosols from the western North Pacific during the 1991 El Ninõ forest fire event occurred in Indonesia (Kawamura et al., 2003). Levoglucosan, galactosan, mannosan, vanillic acid, syringic acid, and 4-hydroxybenzoic acid showed similar diurnal trends with higher concentrations from early morning to noontime in early June (Fig. 5). However, the patterns of dehydroabietic acid and $\beta$-sitosterol were different from the above-mentioned biomass-burning tracers, suggesting that they may be emitted from sources other than wheat straw burning. 

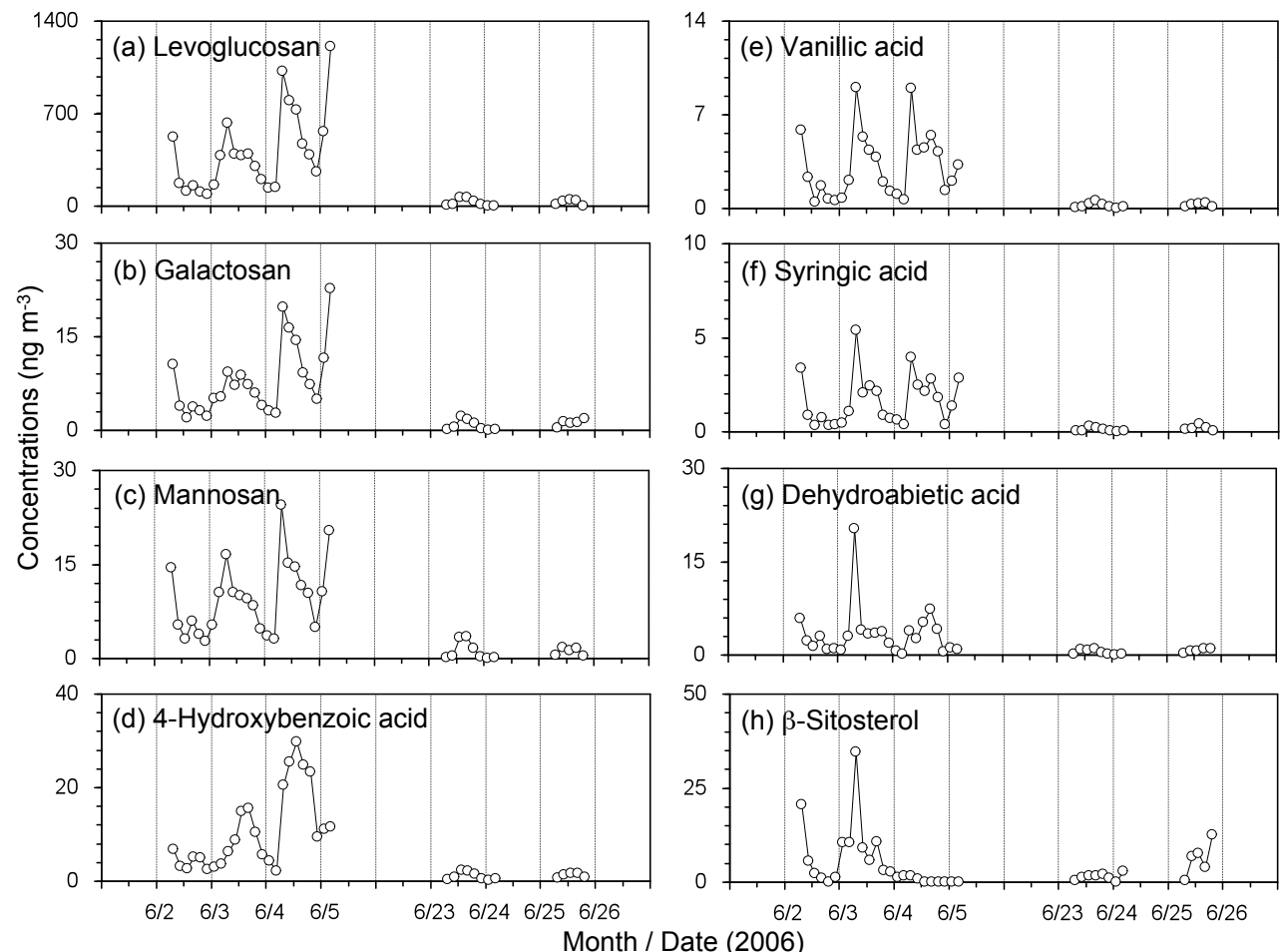

Fig. 5. Diurnal variations of biomass-burning tracers measured in the Mt. Tai aerosols.

\subsubsection{Plastic emission and fossil fuel combustion}

Phthalates are widely used as plasticizers in synthetic polymers or softeners in polyvinylchlorides (PVC) and can be emitted into the atmosphere by evaporation. High levels of phthalate esters (phthalates) have been reported nationwide in Chinese megacities (Wang et al., 2006). Four phthalate esters were detected in the Mt. Tai aerosols, i.e., dimethyl (DMP), diethyl (DEP), diisobutyl (DiBP), and di- $n$-butyl (DnBP) phthalates (Table S1). They were the only compound class with higher levels in late June (13-1070 $\mathrm{ng} \mathrm{m}^{-3}, 400 \mathrm{ng} \mathrm{m}^{-3}$ ) than in early June (39$240 \mathrm{ng} \mathrm{m}^{-3}, 109 \mathrm{ng} \mathrm{m}^{-3}$ ). A strong positive correlation $\left(R^{2}=0.99\right)$ between the concentrations of DiBP and DnBP was found in this study, which indicates that these compounds are commonly used plasticizers and emitted into the atmosphere by evaporation simultaneously. Higher concentrations of phthalates were observed in late June than in early June (Fig. 4i), being consistent with the higher ambient air temperatures observed in late June. The ambient-temperature dependence of phthalates in the atmosphere was further supported by its diurnal trend that peaked at noontime in late June (Fig. 4i). Although such a temperature-dependence is in accordance with higher phthalate concentrations reported in urban aerosols in summer, which was associated with volatilization from substrates (Wang et al., 2006), attentions should be paid that there are other factors causing to such a trend. For example, evaporation of phthalates from sub- strates, concentrations in both gas and particle phases in upwind regions and their transport from the ground surface to the mountaintop, gas/particle partitioning (Teil et al., 2006), photodegradation, as well as wet/dry scavenging (Staples et al., 1997) may influence the atmospheric level of phthalates over Mt. Tai.

Hopanoid hydrocarbons (hopanes) are specific biomarkers of petroleum and coal. A series of hopanes $\left(\mathrm{C}_{27}-\mathrm{C}_{32}\right.$, except for $\mathrm{C}_{28}$ ) were detected in the Mt. Tai aerosols (Table S1) with average concentrations of $1.2 \pm 0.4 \mathrm{ng} \mathrm{m}^{-3}$ in early June and $1.6 \pm 1.0 \mathrm{ng} \mathrm{m}^{-3}$ in late June. In addition to hopanes, polycyclic aromatic hydrocarbons (PAHs) were also detected in the aerosols, ranging from phenanthrene (3ring) to coronene (7-ring). Their total concentrations were $2.7-25 \mathrm{ng} \mathrm{m}^{-3}\left(13 \mathrm{ng} \mathrm{m}^{-3}\right)$ and $0.0-39 \mathrm{ng} \mathrm{m}^{-3}\left(12 \mathrm{ng} \mathrm{m}^{-3}\right)$ in early and late June, respectively. This result indicates that biomass-burning activities contribute little on these PAH species. The dominant PAHs are benzo(b)fluoranthene $(\mathrm{BbF})$, fluoranthene and pyrene (Table S1). The diurnal patterns of total concentrations of hopanes and PAHs were characterized with obvious peaks during daytime in late June (Fig. 4j-k). In addition, their levels are lower than those reported in summertime urban aerosols in China (1.7$168 \mathrm{ng} \mathrm{m}^{-3}$, mean $28 \mathrm{ng} \mathrm{m}^{-3}$ ) (Wang et al., 2006). However, they are much higher than those $\left(0.001-1.6 \mathrm{ng} \mathrm{m}^{-3}\right)$ in marine aerosols including those over the coastal regions in Asia (Fu et al., 2011). 

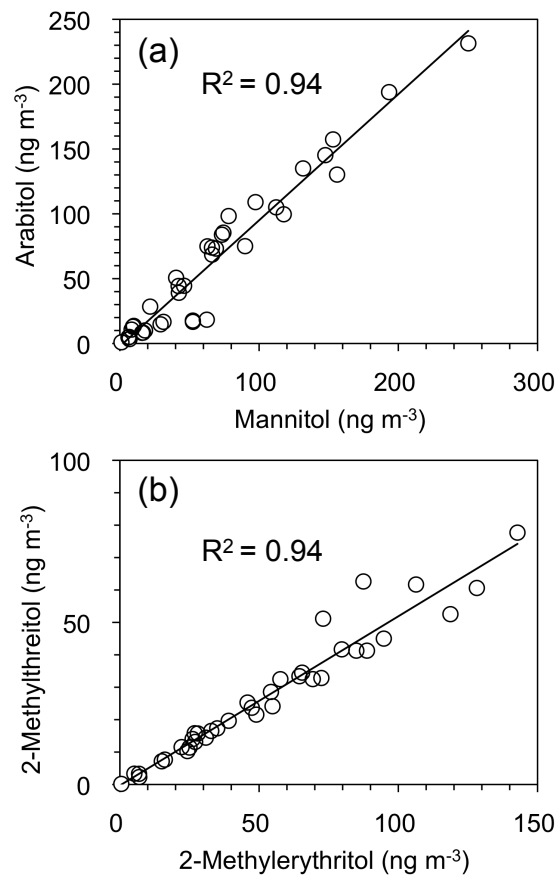

Fig. 6. Corrections between the concentrations of (a) mannitol and arabitol (fungal spore tracers), and (b) 2-methylerythritol and 2methylthreitol (isoprene SOA tracers).

\subsubsection{Primary saccharides and their diurnal variations}

Primary saccharides consisting of fructose, glucose, sucrose, and trehalose were detected in the samples, as well as some sugar alcohols including glycerol, arabitol, mannitol and inositol. Their concentrations ranged from 17 to $247 \mathrm{ng} \mathrm{m}^{-3}$ (78 $\left.\mathrm{ng} \mathrm{m}^{-3}\right)$ and $5.5-87 \mathrm{ng} \mathrm{m}^{-3}\left(43 \mathrm{ng} \mathrm{m}^{-3}\right)$ in early and late June, respectively. Primary saccharides are derived from numerous sources including microorganisms, plants and animals (Simoneit et al., 2004a; Yttri et al., 2007). They have been used as tracers for primary biological aerosol particles (Graham et al., 2003; Elbert et al., 2007; Bauer et al., 2008) and resuspension of surface soil and unpaved road dust (Simoneit et al., 2004a).

A strong positive correlation was found between the concentrations of arabitol and mannitol (Fig. 6a), being consistent with the idea that they are tracers for airborne fungal spores (Lewis and Smith, 1967; Bauer et al., 2008). Fungal spores have been suggested as important sources of primary OC. For example, Bauer et al. (2002) reported that arabitol and mannitol could contribute $4.2 \%$ of coarse aerosol particles in winter; Zhang et al. (2010) reported even higher contributions of these sugar alcohols to OC (4.6-26\%, mean $12 \%$ ) in $\mathrm{PM}_{10}$ collected in a tropical rainforest in South China. Higher concentrations of arabitol, mannitol and trehalose were observed in early June (Fig. 7a) than in late June. Their temporal patterns are also similar to that of levoglucosan (Fig. 5a), suggesting that biomass-burning activi-
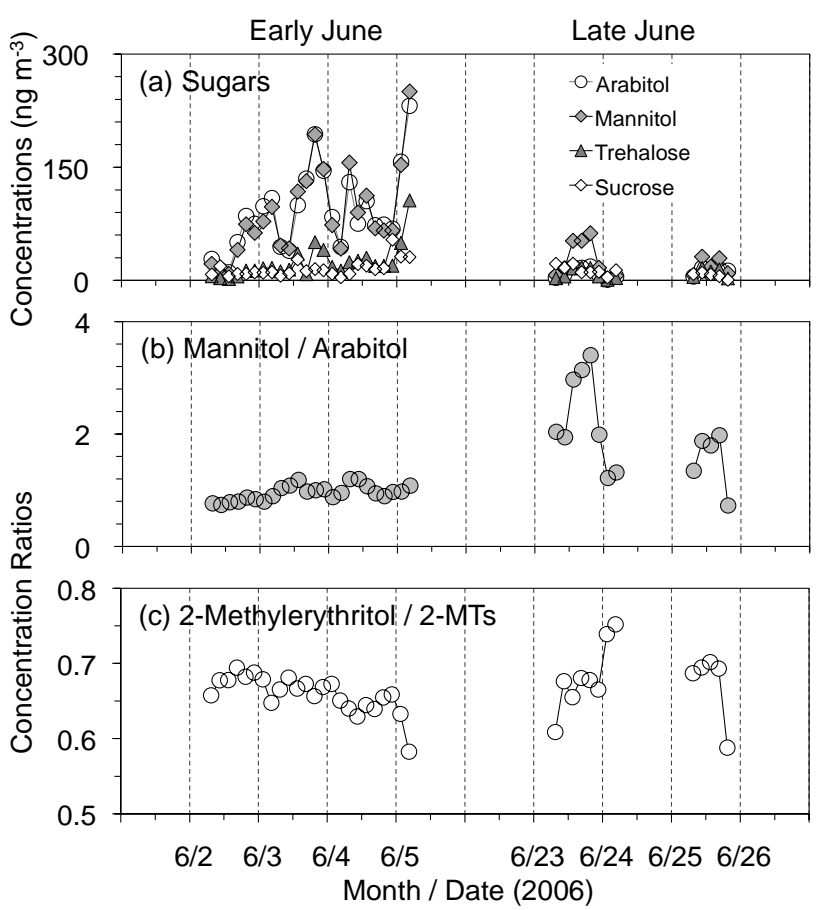

Fig. 7. Diurnal variations of (a) the concentrations of primary saccharides, (b) the mass concentration ratios of mannitol to arabitol and (c) the concentration ratios of 2-methylerythritol to 2-methyltetrols (2-MTs, the sum of 2-methylthreitol and 2methylerythritol) measured in the Mt. Tai aerosols.

ties can enhance the emission of sugar alcohols at a certain level. This idea is supported by the correlation $\left(R^{2}=0.54\right.$, $n=37$, not shown as a figure) between levoglucosan and the sum of arabitol and mannitol. Recently, Yang et al. (2012) observed elevated fungal tracers in atmospheric aerosols due to biomass burning in Chengdu City, China. One potential process is that airborne fungal spores can be adsorbed onto smoke particles and then co-transported to the summit of Mt. Tai.

Interestingly, the mass concentration ratios of mannitol to arabitol showed a flat pattern in early June with a range of 0.74-1.2 (mean 0.95). While in late June, a clear diurnal trend was observed with a peak during late afternoon; their ratios ranged from 0.73 to 3.4 (mean 2.0) (Fig. 7b). This may further suggest that biomass burning can simultaneously emit arabitol and mannitol at a similar level with lower concentration ratios of mannitol to arabitol in early June. In late June when the influence of biomass burning was diminished, these sugar alcohols were mainly of fungal-spore origin. Different fungal species may contain various levels of sugar alcohols; the fungal activities varied with time within a day (Elbert et al., 2007). In a previous study conducted during the same campaign in late June, higher mannitol-toarabitol ratios were also observed in the fine aerosol particles $\left(\mathrm{PM}_{2.5}\right)$ collected at daytime than those at nighttime 
(Wang et al., 2009a). In contrast, in Norwegian urban and rural background sites, Yttri et al. (2011b) found that the mannitol-to-arabitol ratios had a diurnal variation in summer, with a higher ratio during night compared to the rest of day. Such a conflict may be caused by the complexity of fungal species (more than one million) in the Earth's biosphere and atmosphere. The discharge of fungal spores into the atmosphere from different fungi is highly variable, depending on season, weather, location, as well as time of day (Elbert et al., 2007; Zhang et al., 2010; Burshtain et al., 2011; Després et al., 2012; Fröhlich-Nowoisky et al., 2012).

\subsubsection{Aliphatic lipid composition: the influence of biomass burning}

$n$-alkanes $\left(\mathrm{C}_{20}-\mathrm{C}_{36}\right)$ showed stronger odd/even carbon number predominance (carbon preference index, CPI) in early June $(\mathrm{CPI}=3.9)$ than in late June $(\mathrm{CPI}=2.1)$ with carbon number maxima $\left(\mathrm{C}_{\max }\right)$ at $\mathrm{C}_{29}$ (Fig. S3a). CPI value is close to unity in anthropogenic sources (e.g., petroleum), while it is around 10 in higher plant waxes. Our results demonstrate that the Mt. Tai aerosols were heavily influenced by the emission of higher plant waxes from biomass burning in early June, while in late June they were more likely affected by petroleum residues.

A homologous series of saturated fatty acids $\left(\mathrm{C}_{10: 0}-\mathrm{C}_{32: 0}\right)$ were detected in the samples (Table S1). A strong even carbon number predominance was observed with $\mathrm{C}_{\max }$ at $\mathrm{C}_{16: 0}$ and $\mathrm{C}_{28: 0}$ (Fig. S3b). Higher molecular weight (HMW) fatty acids $\left(\geq C_{20}\right)$ are derived from terrestrial higher plant waxes, while LMW fatty acids $\left(\leq \mathrm{C}_{19}\right)$ have multiple sources such as vascular plants, microbes and marine phytoplankton as well as kitchen emissions (Simoneit and Mazurek, 1982; Rogge et al., 1993; Kawamura et al., 2003). The molecular distributions of fatty acids showed a bimodal pattern with two peaks at $\mathrm{C}_{16: 0}$ and $\mathrm{C}_{28: 0}$ (Fig. S3b). Much higher concentrations of HMW fatty acids $\left(\mathrm{C}_{20: 0}-\mathrm{C}_{32: 0}\right)$ in early June than in late June should be caused by the enhanced wheat straw burning in early June, being similar to the results of $n$-alkanes. Similar molecular distributions of $n$-alkanes and fatty acids were also reported in urban aerosols collected during a severe haze event in Nanjing, East China (Wang et al., 2009b). Such an urban haze event was also caused by wheat straw burning in the North China Plain in summer 2007.

Normal $\mathrm{C}_{18}-\mathrm{C}_{32}$ fatty alcohols were detected in the aerosols. Their distributions are characterized by even carbon number predominance with a maximum at $\mathrm{C}_{28}$ (Fig. S3c). The homologues $<\mathrm{C}_{20}$ are abundantly present in soil microbes and marine biota, while the homologues $>\mathrm{C}_{20}$ are specific to terrestrial higher plants and loess deposits. Simoneit (2002) reported that biomass burning processes can emit a large amount of fatty alcohols and fatty acids into the air.
In early June, the concentration ranges of $n$-alkanes, fatty acids and fatty alcohols are $54.8-599 \mathrm{ng} \mathrm{m}^{-3}, 76.1-$ $941 \mathrm{ng} \mathrm{m}^{-3}$ and $30.0-954 \mathrm{ng} \mathrm{m}^{-3}$, respectively, which are several times higher than those in late June (Table S1). The temporal patterns of these aliphatic lipids (Fig. 4a-c) are similar to those of anhydrosugars such as levoglucosan (Fig. 5a). Furthermore, a strong correlation $\left(R^{2}=0.74\right)$ is found between levoglucosan and plant wax $n$-alkanes (Fig. S1b). These results suggest that biomass burning is a significant source of aliphatic lipids in the atmosphere.

\subsubsection{Aromatic and poly-acids}

Benzoic acid has been proposed as an indicator of primary pollutant in the motor exhausts (Kawamura et al., 1985) and a secondary product from photochemical degradation of alkyl benzenes (e.g., toluene) emitted by automobiles (Suh et al., 2003). Higher levels of benzoic acid were observed in late June $\left(0.88-57 \mathrm{ng} \mathrm{m}^{-3}\right.$, mean $\left.9.8 \mathrm{ng} \mathrm{m}^{-3}\right)$ than those in early June $\left(2.4-12 \mathrm{ng} \mathrm{m}^{-3}, 5.8 \mathrm{ng} \mathrm{m}^{-3}\right)$. Interestingly, the temporal variation of benzoic acid (Fig. S2a) was similar to those of toluic acids (Fig. S2b), suggesting a close source. However, the temporal patterns of phthalic acids (Fig. S2c) were consistent with those of biomass burning tracers. Their isomeric composition was characterized by a predominance of $o$-phthalic acid, being consistent with those reported in the Arctic aerosols (Fu et al., 2009).

Little is known about the concentrations of hydroxybenzoic acids in ambient aerosols, especially for salicylic acid (van Pinxteren and Herrmann, 2007). The concentrations of salicylic acid ranged from 1.1 to $14 \mathrm{ng} \mathrm{m}^{-3}\left(6.2 \mathrm{ng} \mathrm{m}^{-3}\right)$ in early June, which were higher than those in late June $\left(0.18-3.5 \mathrm{ng} \mathrm{m}^{-3}, 1.9 \mathrm{ng} \mathrm{m}^{-3}\right)$. Salicylic acid, together with phthalic acid, has been identified as metal binding agents in humic acids (Gamble et al., 1980). Thus, the detection of salicylic acid in the atmosphere suggests that it may act as metal binding sites in humic-like substances (HULIS), a major component of ambient aerosols, affecting the biogeochemical behaviors of heavy metals (e.g., $\mathrm{Hg}$ ).

Polyacids including glyceric, malic, tartaric, citric, and tricarballylic acids were detected in the samples. Polyacids are considered as secondary oxidation products of precursor organic compounds. In addition, biomass burning can also emit malic acid and other dicarboxylic acids and/or their precursors into the atmosphere (Kundu et al., 2010). A good correlation $\left(R^{2}=0.70\right)$ was found between levoglucosan and malic acid (Fig. S1c), supporting such an idea. Furthermore, the diurnal variation of phthalic acids and salicylic acid (Fig. S2) were similar to that of malic acid. Phthalic acids have been proposed as a surrogate for the contributions of secondary oxidation to organic aerosols. The diurnal patterns of benzoic acid and toluic acids (Fig. S2) were different from levoglucosan and malic acid, and were characterized with high concentration peaks in late June, indicating that biomass burning contributes little to these aromatic acids. 

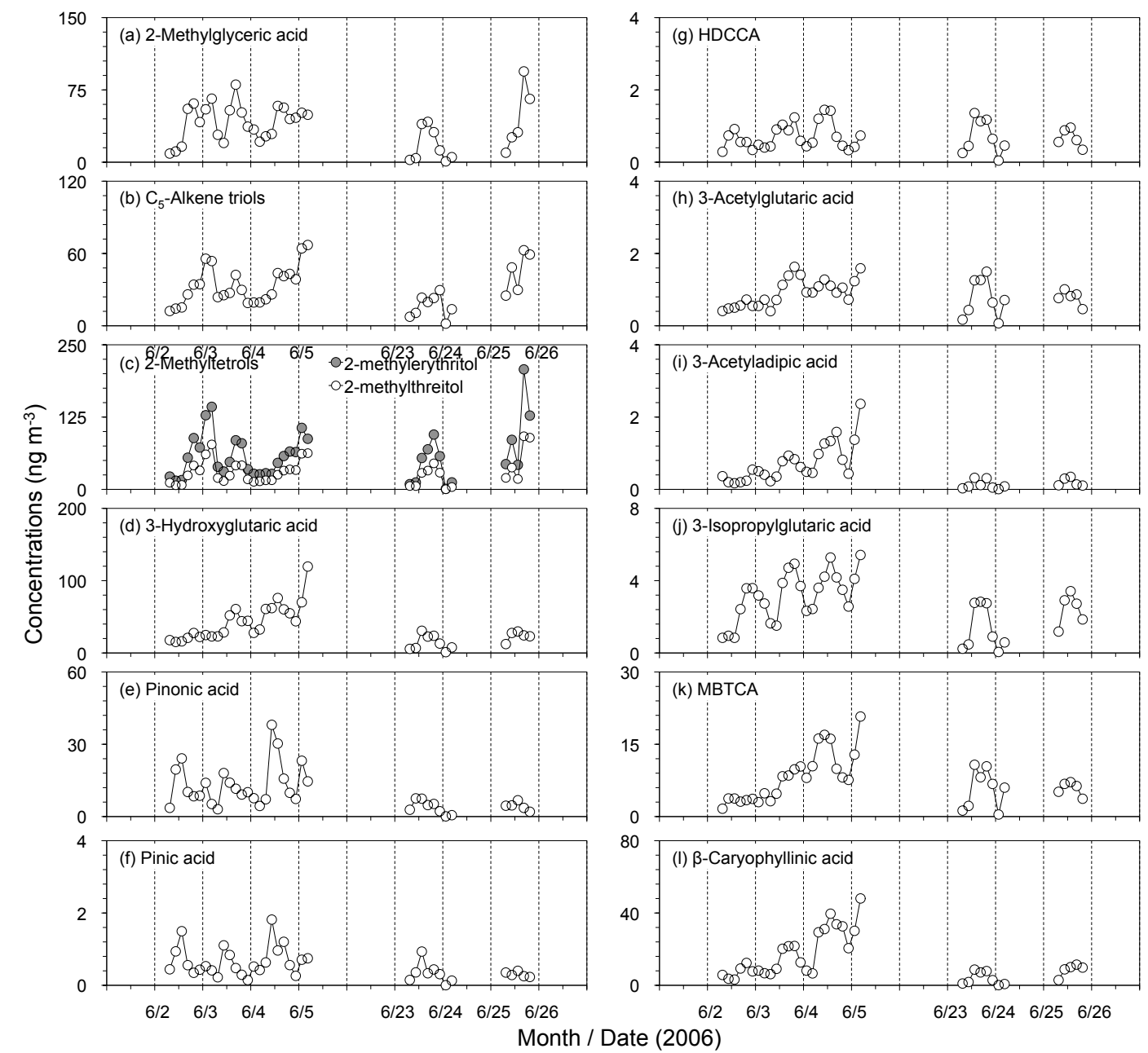

Fig. 8. Diurnal variations of biogenic SOA tracers detected in the Mt. Tai aerosols.

\subsubsection{Biogenic SOA tracers}

Six compounds were identified as isoprene oxidation products in the Mt. Tai aerosols, including two 2-methyltetrols (2-MTs, the sum of 2-methylthreitol and 2-methylerythritol), 2-methylglyceric acid and three $\mathrm{C}_{5}$-alkene triols (Table S1). Concentration ranges of 2-methylthreitol and 2methylerythritol were $7.2-78 \mathrm{ng} \mathrm{m}^{-3}\left(30 \mathrm{ng} \mathrm{m}^{-3}\right)$ and $15-$ $143 \mathrm{ng} \mathrm{m}^{-3}\left(58 \mathrm{ng} \mathrm{m}^{-3}\right)$ in early June versus $0.18-53 \mathrm{ng} \mathrm{m}^{-3}$ $\left(21 \mathrm{ng} \mathrm{m}^{-3}\right)$ and $0.51-119 \mathrm{ng} \mathrm{m}^{-3}\left(43 \mathrm{ng} \mathrm{m}^{-3}\right)$ in late June, respectively. A good correlation was found between 2methylerythritol and 2-methylthreitol (Fig. 6b), suggesting a similar photochemical source from the oxidation of isoprene (Claeys et al., 2004). $\mathrm{C}_{5}$-alkene triols were detected in all the samples with concentrations being 2-3 times lower than those of 2-methyltetrols. They are much lower than those (ca. $50 \mathrm{ng} \mathrm{m}^{-3}$ ) reported in subtropical Hong Kong ( Hu et al., 2008). However, their total concentrations are higher than those reported in other studies from midlatitutes; e.g., a Californian pine forest, USA $\left(3.47 \mathrm{ng} \mathrm{m}^{-3}\right)$ (Cahill et al.,
2006), and Jülich, Germany (1.6-4.9 $\mathrm{ng} \mathrm{m}^{-3}$ ) (Kourtchev et al., 2008). The concentration ranges of 2 -methylglyceric acid were $9.0-81 \mathrm{ng} \mathrm{m}^{-3}\left(42 \mathrm{ng} \mathrm{m}^{-3}\right)$ in early June and $0.86-$ $94 \mathrm{ng} \mathrm{m}^{-3}\left(28 \mathrm{ng} \mathrm{m}^{-3}\right)$ in late June.

Oxidation products of $\alpha-/ \beta$-pinene were also detected, including pinonic acid, pinic acid, 3-hydroxyglutaric acid (3-HGA), 3-(2-hydroxyethyl)-2,2-dimethylcyclobutane carboxylic acid (HDCCA), 3-acetylglutaric acid, 3acetyladipic acid, 3-isopropylglutaric acid, and 3-methyl1,2,3-butanetricarboxylic acid (MBTCA). 3-HGA can be generated in smog chamber experiments with UV-irradiated $\alpha$-pinene in the presence of $\mathrm{NO}_{\mathrm{x}}$ (Claeys et al., 2007). The formation of MBTCA is explained by further reaction of cis-pinonic acid with $\mathrm{OH}$ radical (Szmigielski et al., 2007). $\beta$-Caryophyllinic acid, formed either by ozonolysis or photo-oxidation of $\beta$-caryophyllene (Jaoui et al., 2007), was identified in all the samples with concentrations of $0.05-48 \mathrm{ng} \mathrm{m}^{-3}$.

Figure 8 presents the diurnal variations of biogenic SOA tracers. In late June, all the polar organic marker compounds 


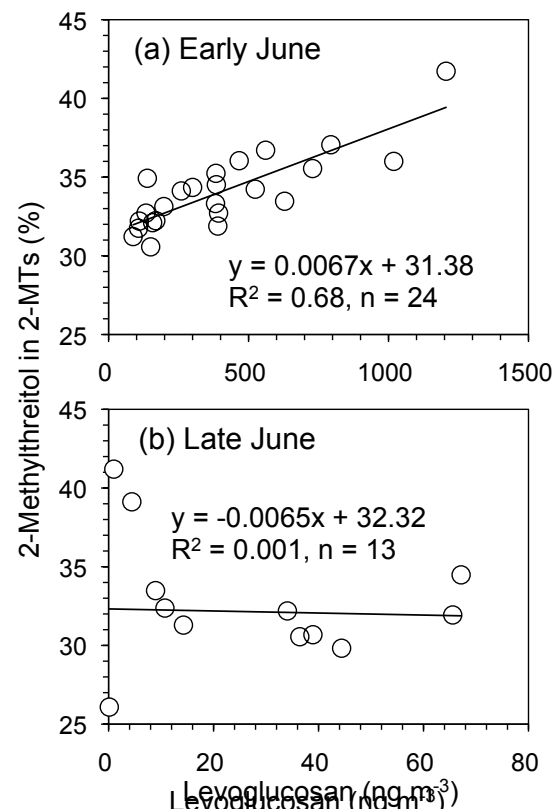

Fig. 9. Relationships between the concentrations of levoglucosan and the percentages of 2-methylthreitol in 2-methyltetrols (2-MTs, the sum of 2-methylthreitol and 2-methylerythritol) for the samples collected in (a) early June and (b) late June.

showed similar patterns to each other with concentration peaks in the afternoon, suggesting that they were derived from similar source regions. In early June, the isoprene oxidation tracers also showed similar temporal trends each other, with higher concentrations during late afternoon to midnight (Fig. 8a-c). These temporal patterns are different from those of biomass burning tracers, which showed peaks in early morning (Fig. 5). Although 2-methylthreitol correlated well with 2-methylerythritol (Fig. 6b), the concentration ratios of 2-methylerthritol to 2-methyltetrols varied with time of the day (Fig. 7c), especially in late June. Such a variation may indicate that the formation processes and/or the sources of 2-methylthreitol and 2-methylerythritol are varied within a day. A recent study (Nozière et al., 2011) reported that 2-methyltetrols could be of biogenic origin at a certain level. In addition, we found an intriguing correlation $\left(R^{2}=0.68\right)$ between levoglucosan and the mass concentration ratios of 2-methylthreitol to 2-methyltetrols in early June (Fig. 9a), while such a correlation was not found in late June (Fig. 9b). This indicates that the biomass-burning activities in early June could significantly influence the formation and/or emission of 2-methylthreitol rather than 2-methylerythritol, a point warrants further study.

Monoterpene SOA tracers such as pinonic acid, pinic acid and HDCCA showed similar diurnal patterns each other with higher concentrations at daytime than nighttime in early June (Fig. 8e-g). In contrast, other monoterpene SOA tracers such as 3-hydroxyglutaric acid, 3-acetyladipic acid and MBTCA, as well as the sesquiterpene SOA tracer, $\beta$-caryophyllinic acid, did not show the diurnal patterns similar to those of the former SOA tracers such as pinonic and pinic acids. This difference suggests that the time scales of the formation of the latter compounds are longer, which is consistent with the fact that they are later-generation oxidation products of $\alpha$-pinene. Furthermore, the diurnal patterns of these later-generation products such as 3-hydroxyglutaric acid and MBTCA, together with $\beta$-caryophyllinic acid, exhibited diurnal trends similar to malic acid and levoglucosan. For example, levoglucosan correlated well with 3-hydroxyglutaric, 3-acetyladipic and $\beta$-caryophyllinic acids (Fig. S1d-f), while no correlations were found between levoglucosan and isoprene SOA tracers. These results suggest that crop-residue burning activities occurring in the North China Plain may enhance the emission of a certain amount of mono- and sesqui-terpenes rather than isoprene. The emitted biogenic VOCs can be rapidly oxidized in the presence of high levels of $\mathrm{O}_{3}$ and $\mathrm{NO}_{\mathrm{x}}$ during the campaign ( $\mathrm{Li}$ et al., 2008); the oxidation products are further adsorbed or condensed onto the biomass-burning aerosols and transported simultaneously to the summit of Mt. Tai. In addition, WSOC is generally considered as components of secondary origin. The positive correlation between levoglucosan and WSOC that was discussed in Sect. 3.3.1 suggests that biomass burning can significantly contribute to the SOA formation during the sampling period.

\subsection{Source apportionment based on the measured organics}

To better understand the sources of organic aerosols over Mt. Tai, organic compound classes quantified in the aerosols can be roughly apportioned to five emission sources and one atmospheric oxidation products as follows: (a) "plant emission" characterized by higher plant wax $n$-alkanes, HMW fatty acids and fatty alcohols $\left(>\mathrm{C}_{20}\right)$; (b) "marine/microbial source" mainly reflected from LMW fatty acids and fatty alcohols $\left(\leq \mathrm{C}_{20}\right)$, and sterols; (c) "biomass burning" characterized by levoglucosan and its isomers, $\beta$-sitosterol, 4hydroxybenzoic acid, and lignin/resin acids; (d) "fossil fuel combustion" characterized by petroleum-derived $n$-alkanes, hopanes, and PAHs; (e) "soil/fungal spore/pollen" characterized by primary saccharides and reduced sugars; and (f) "photo-oxidation" reflected by biogenic SOA tracers, aromatic acids, and polyacids.

The above-categorized organic tracers in the Mt. Tai aerosols are apportioned. In early June (Fig. 10a), plant emission $(38 \%)$, biomass burning $(17 \%)$ and photooxidation $(17 \%)$ were the major contributors, while soil/fungal spore/pollen $(9 \%)$, fossil fuel combustion $(7 \%)$, plastic emission $(6 \%)$ and marine/microbial source $(6 \%)$ were minor contributors. In late June (Fig. 10b), however, plastic emission became the most important contributor (49\%) when the ambient temperature was higher than in early June, followed by photooxidation $(17 \%)$ and marine/microbial source $(10 \%)$, whereas biomass burning $(3 \%)$ became the 


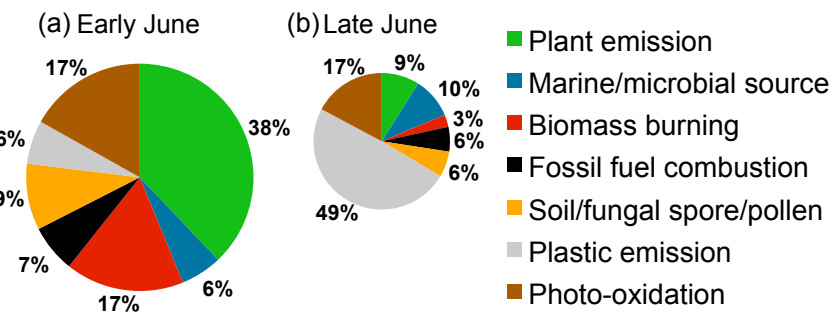

Fig. 10. Pie diagrams showing the relative abundances of organic species detected in the Mt. Tai aerosols, which are roughly grouped according to their potential sources. The sizes of the pie diagrams are proportional to the average ambient OC concentrations during each sampling period.

least important contributor. It should be noted that this source apportionment approach is useful to roughly estimate the relative contribution from different emission sources to organic aerosols. Many organic species in atmospheric aerosols may have multiple sources, and thus a potential overlapping cannot be excluded using such an approach (Simoneit et al., 2004b).

In order to obtain further information on the relative abundances of organic aerosols from primary and secondary sources, some tracer-based methods were used to estimate their contributions to aerosol OC. Here, the measured concentrations of mannitol were used to calculate the contributions of fungal spores to OC (Bauer et al., 2008). The average OC/levoglucosan ratio of 12.3 measured in Rondônia aerosols (Graham et al., 2002) was obtained to estimate the biomass-burning-derived OC. In addition, the measured biogenic SOA tracers were used to estimate the secondary organic carbon (SOC) formed from the oxidation of isoprene, $\alpha$-pinene and $\beta$-caryophyllene using a tracer-based method (Kleindienst et al., 2007). It should be noted that such estimation might suffer from a large uncertainty; a point that has been discussed in details by Yttri et al. (2011a, b) and El Haddad et al. (2011). However, the results can still provide meaningful insight into their diurnal trends.

The results of the tracer-based methods are presented in Table 2 and Fig. 11. In early June, biomass-burningderived OC, ranging from $1.1-15 \mu \mathrm{gC} \mathrm{m}^{-3}\left(5.0 \mu \mathrm{gC} \mathrm{m}^{-3}\right)$, was by far the dominant source, which accounts for 6.0 $64 \%(24 \%)$ of OC in the Mt. Tai aerosols. Fungal-sporederived OC $\left(0.69 \mu \mathrm{gC} \mathrm{m}^{-3}\right)$ was comparable with those of biogenic isoprene- and $\beta$-caryophyllene-derived SOC. $\alpha$ Pinene-derived SOC was rather minor $\left(0.04-0.30 \mu \mathrm{gC} \mathrm{m}{ }^{-3}\right.$, $\left.0.13 \mu \mathrm{gC} \mathrm{m}^{-3}\right)$, only accounting for $0.4-1.6 \%(0.7 \%)$ of OC. In total, these biogenic primary and secondary sources can contribute $16-74 \%$ of OC with an average of $36 \%$. In late June, however, isoprene-derived SOC became the dominant contributor to OC $(0.5-17 \%, 6.6 \%)$, followed by biomass-burning $(3.0 \%)$ and fungal-spore emissions $(2.0 \%)$. The contribution of these sources to OC in late June (1.3$27 \%, 14 \%)$ is much lower than that in early June. Such a
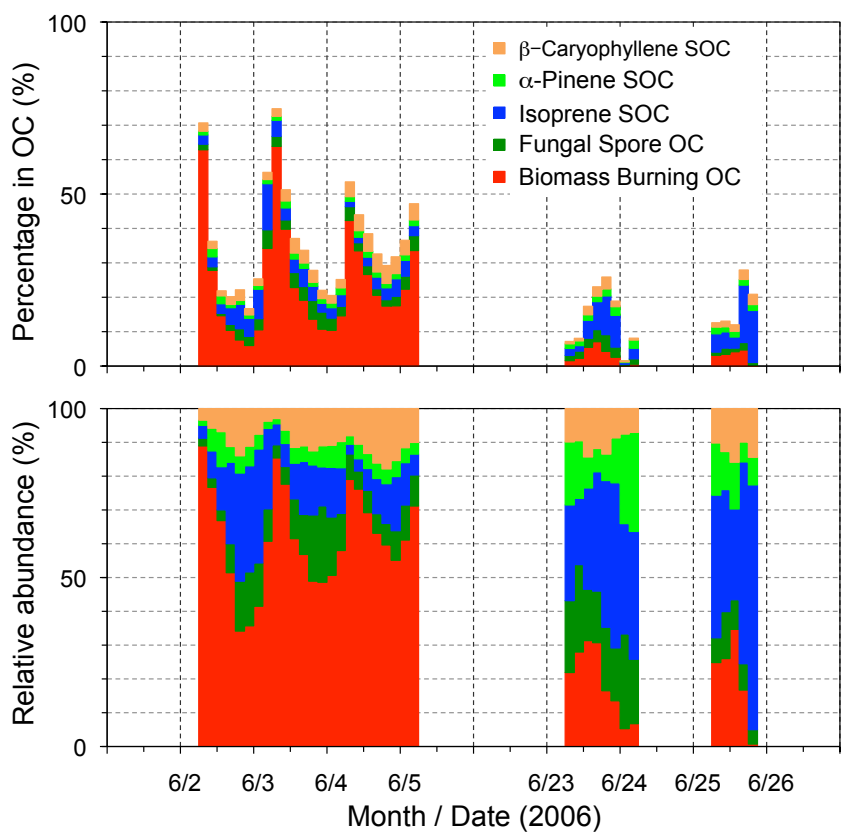

Fig. 11. (a) Contributions of primary organic carbon from biomass burning and fungal spores, and secondary organic carbon (SOC) from isoprene, $\alpha$-pinene and $\beta$-caryophyllene to organic carbon (as a percentage) in the time-resolved $(3 \mathrm{~h}$ ) mountain aerosols, and (b) their relative abundances.

difference between early June and late June indicates that wheat-straw burning activities in early summer strongly impact on the molecular compositions of organic aerosols over Mt. Tai in East China, which may potentially influence the regional climate.

\subsection{Stable carbon isotopic composition of TC: the impact of biomass burning}

Several decades ago, Smith and Epstain (1971) reported that there is a carbon isotope ratio $\left(\delta^{13} \mathrm{C}\right)$ difference between $\mathrm{C}_{3}$ and $\mathrm{C}_{4}$ plants. $\mathrm{C}_{3}$ plants, which fix $\mathrm{CO}_{2}$ via ribulose bisphosphate carboxylase in photosynthesis, have $\delta^{13} \mathrm{C}$ values typically in the range of -23 to $-30 \%$. However, $\mathrm{C}_{4}$ and CAM plants, which fix $\mathrm{CO}_{2}$ via P-enolpyruvate carboxylase, have average $\delta^{13} \mathrm{C}$ values of about $-13 \%$. Thus, stable carbon isotope ratios can be used to distinguish $\mathrm{C}_{3}$ plants from $\mathrm{C}_{4}$ and CAM plants. Previous studies of atmospheric aerosols have differentiated the influence of anthropogenic from natural (marine and continental) aerosol emissions (Cachier, 1989; Narukawa et al., 2008) as well as the influence of biomass burning (Narukawa et al., 1999; Martinelli et al., 2002).

In early June, the active field burning of wheat straws in the North China Plain heavily influenced the tropospheric aerosols collected at the summit of Mt. Tai. Wheat is a typical $\mathrm{C}_{3}$ plant. Thus, the influence of the smoke aerosols from wheat-straw burning should have isotopically lighter $\delta^{13} \mathrm{C}$ 
Table 2. Summary of organic carbon concentrations $\left(\mu \mathrm{gC} \mathrm{m}^{-3}\right)$ from different sources and their contributions in aerosol OC $(\%)$.

\begin{tabular}{llllllll}
\hline \multirow{2}{*}{ Component } & \multicolumn{2}{c}{ Early June $(n=24)$} & & \multicolumn{3}{c}{ Late June $(n=13)$} \\
\cline { 2 - 3 } \cline { 7 - 8 } & range & mean & std & & range & mean & std \\
\hline Concentration $\left(\mu \mathrm{gC} \mathrm{m}^{-3}\right)$ & & & & & & & \\
\hline Biomass burning OC & $1.1-15$ & 5.0 & 3.7 & & $0.002-0.83$ & 0.31 & 0.30 \\
Fungal spore OC & $0.06-1.9$ & 0.69 & 0.45 & & $0.009-0.48$ & 0.18 & 0.16 \\
Isoprene SOC & $0.22-1.9$ & 0.84 & 0.46 & & $0.01-1.7$ & 0.60 & 0.53 \\
$\alpha$-Pinene SOC & $0.11-0.72$ & 0.31 & 0.16 & & $0.008-0.24$ & 0.14 & 0.07 \\
$\beta$-Caryophyllene SOC & $0.14-2.1$ & 0.78 & 0.56 & & $0.002-0.38$ & 0.17 & 0.14 \\
Subtotal & $2.0-21$ & 7.6 & 4.6 & & $0.03-2.9$ & 1.4 & 1.0 \\
\hline Percentage in aerosol OC $(\%)$ & & & & & & & \\
\hline Biomass burning OC & $6.0-64$ & 24 & 16 & & $0.1-7.1$ & 3.0 & 2.1 \\
Fungal spore OC & $0.7-5.5$ & 3.1 & 1.3 & & $0.4-4.9$ & 2.0 & 1.2 \\
Isoprene SOC & $1.5-13$ & 4.3 & 2.5 & & $0.5-17$ & 6.6 & 5.2 \\
$\alpha$-Pinene SOC & $0.9-2.4$ & 1.5 & 0.4 & & $0.4-2.5$ & 1.7 & 0.5 \\
$\beta$-Caryophyllene SOC & $1.5-5.3$ & 3.3 & 1.3 & & $0.1-3.5$ & 1.8 & 1.1 \\
Subtotal & $17-75$ & 36 & 16 & & $1.5-28$ & 15 & 8.0 \\
\hline
\end{tabular}

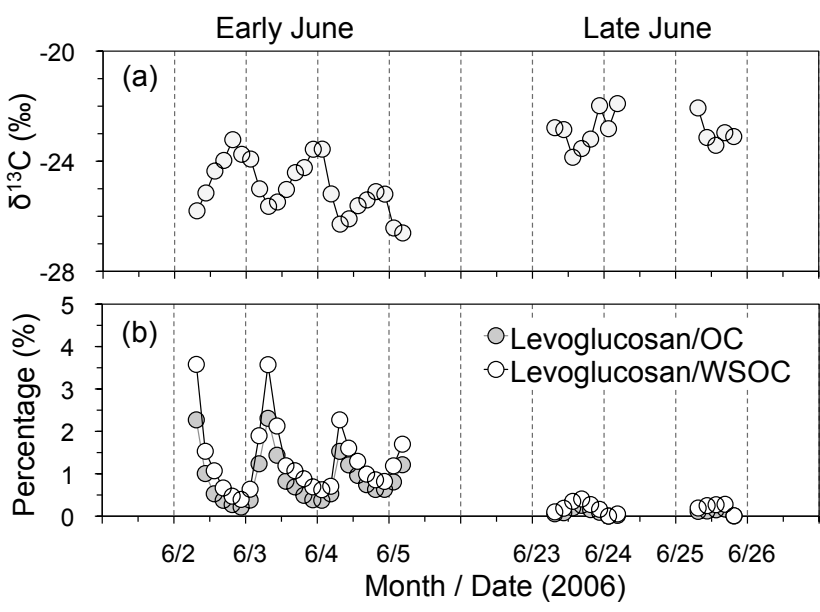

Fig. 12. Diurnal variations of (a) stable carbon isotope ratios of total carbon, and (b) the percentages of levoglucosan-C in $\mathrm{OC}$ and WSOC.

values. Figure 12a presents the diurnal variations of stable carbon isotope ratios of TC in the Mt. Tai aerosols. In early June, $\delta^{13} \mathrm{C}$ values ranged from -26.6 to $-23.2 \%$ (mean $-25.0 \%$ ), which were lower than those $(-23.9$ to $-21.9 \%$, mean $-22.9 \%$ ) in late June. In addition, a clear diurnal pattern was observed for $\delta^{13} \mathrm{C}$. Higher carbon isotope ratios were generally observed in mid-night when the summit of Mt. Tai exists in the free troposphere. Lower isotope ratios were observed in early morning when the contributions of levoglucosan to OC and WSOC maximized up to $2.3 \%$ and $3.6 \%$, respectively (Fig. 12b). A nonlinear relationship was found between levoglucosan concentrations and $\delta^{13} \mathrm{C}$ values as shown in Eq. (1) with a strong correlation coefficient $\left(R^{2}=0.86\right.$, Fig. 13).

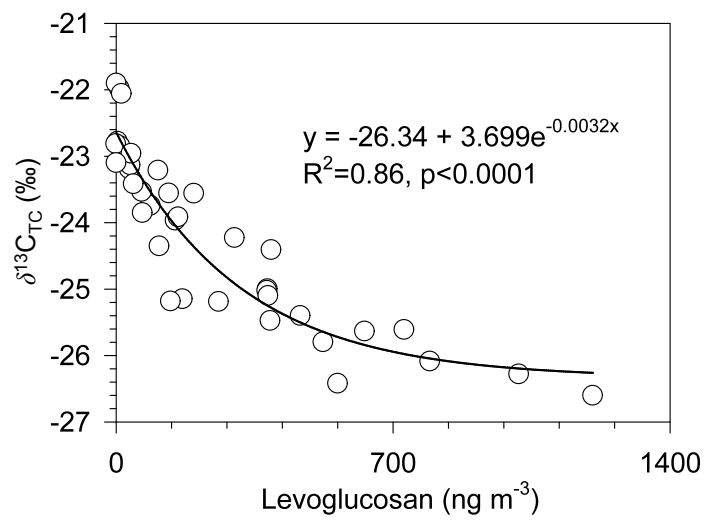

Fig. 13. A nonlinear correlation (exponential decay) observed between the concentrations of levoglucosan and stable carbon isotope ratios of total carbon $\left(\delta^{13} \mathrm{C}_{\mathrm{TC}}\right)$ in the Mt. Tai aerosols collected during MTX2006.

$\delta^{13} \mathrm{C}_{\mathrm{TC}}=-26.34+3.699 e^{-0.0032[L]}$,

where $[L]$ represents the concentration of levoglucosan. Such a negative correlation indicates that the burning activities of wheat straws significantly influence of organic aerosol composition over Mt. Tai in early summer, lowering the stable carbon isotope ratios of aerosol carbon. Using the Eq. (1), the $\delta^{13} \mathrm{C}$ of TC during the burning season can be roughly estimated by the levels of levoglucosan. Assuming that the impact of biomass burning is negligible $([L]=0)$, the $\delta^{13} \mathrm{C}_{\mathrm{TC}}$ of $-22.6 \%$ was estimated for the background aerosols over Mt. Tai in summer.

Rudolph et al. (2000) reported that the $\delta^{13} \mathrm{C}$ values of VOCs that can form SOA should become lower during long 
range atmospheric transport due to the kinetic isotope effects for the reactions of hydrocarbons with $\mathrm{OH}$ radicals. Irei et al. (2006) also reported that the $\delta^{13} \mathrm{C}$ values of $\mathrm{SOA}$ formed by $\mathrm{OH}$ radical-induced reactions of toluene are $0.6 \pm 0.2 \%$ o lower than those of the precursors. However, in this study, isotopically heavier values of $\delta^{13} \mathrm{C}_{\mathrm{TC}}$ (up to $-21.9 \%$ ) were observed from late afternoon to midnight (Fig. 12a) when the relative abundance of biogenic SOA was enhanced (Fig. 11b). This phenomenon indicates that SOA formed from the oxidation of biogenic VOCs may have higher isotope ratios than biomass burning aerosols and other primary sources. For example, studies have reported that oxalic acid showed much higher isotope ratios in both urban $(-17.1 \%$ ) (Pavuluri et al., 2011) and marine aerosols $(-16.8 \%$ ) (Wang and Kawamura, 2006). Oxalic acid is one of the end products for the photo-oxidation of organic aerosols and one of the dominant organic acids in aerosol phase in the atmosphere (Kawamura and Sakaguchi, 1999). A recent laboratory study (Pavuluri and Kawamura, 2012) provides an evidence for the isotopic enrichment of ${ }^{13} \mathrm{C}$ in oxalic acid due to photochemical aging.

\section{Summary and conclusions}

During the summer campaign at the summit of Mt. Tai in the North China Plain, heavy biomass-burning activities occurred in early June when most of the organic compounds identified in aerosols are more abundant than those in late June. Concentrations of total quantified organic compounds in the aerosols in early June (595-5730 $\mathrm{ng} \mathrm{m}^{-3}$, mean $2040 \mathrm{ng} \mathrm{m}^{-3}$ ) were more than 2 times higher than those in late June $\left(35-1960 \mathrm{ng} \mathrm{m}^{-3}, 908 \mathrm{ng} \mathrm{m}^{-3}\right)$. The total identified organics accounted for 3.4-8.0\% (mean 5.7\%) and 1.0$11 \%(6.7 \%)$ of OC in early and late June, respectively. Although these values may be underestimated due to a potential evaporative loss of semi-volatile compounds during aerosol sampling, this study suggests that the major portion (90\%) of organic aerosols over Mt. Tai is still not specified at a molecular level. The unknown portion may include dicarboxylic acids, oligmers, organosulfates, organic nitrates, amino acids, humic-like substances, and other high molecular weight organic compounds such as proteins that are derived from primary biological aerosols.

The predominance of anhydrosugars, together with lignin products and aliphatic lipids, suggests that the field burning of wheat straws is an important primary source of organic aerosols in the North China Plain in early June. Meanwhile, strong correlations between levoglucosan and SOA tracers such as malic acid, 3-hydroxyglutairc acid and $\beta$ caryophyllinic acid suggest that the open burning of crop residues is also a significant source of SOA and/or their precursors in this region. In addition, levoglucosan correlated well with stable carbon isotope ratios $\left(\delta^{13} \mathrm{C}\right)$ of TC. The diurnal variations of organic compound classes in early June were different from those in late June. The concentration ratios of mannitol to arabitol and 2-methylerythritol to 2methyltetreols also showed different diurnal patterns in early June compared with those in late June. These results indicate that biomass-burning activities can significantly influence the organic molecular composition and stable carbon isotopic composition of tropospheric aerosols in the North China Plain in early summer, and thus play an important role in atmospheric chemistry and regional climate.

\section{Supplementary material related to this article is available online at: http://www.atmos-chem-phys.net/12/ 8359/2012/acp-12-8359-2012-supplement.pdf.}

Acknowledgements. This study is partly supported by the Japanese Ministry of Education, Culture, Sports, Science and Technology (MEXT) through grant-in-aid Nos. 17340166 and 19204055 and by the Environment Research and Technology Development Fund (B0903) of the Ministry of the Environment, Japan. We acknowledge the financial support by the Global Environment Research Fund (B-051) of the Ministry of the Environment, Japan for the shipping of the instruments to Mt. Tai. P.F. appreciates the financial support from the Japan Society for the Promotion of Science (JSPS) and the Chinese National Natural Science Foundation (No. 41175106). We thank two anonymous reviewers for helpful comments and suggestions which improved the manuscript.

Edited by: S. C. Liu

\section{References}

Andreae, M. O. and Crutzen, P. J.: Atmospheric aerosols: Biogeochemical sources and role in atmospheric chemistry, Science, 276, 1052-1058, 1997.

Andreae, M. O. and Rosenfeld, D.: Aerosol-cloud-precipitation interactions. Part 1. The nature and sources of cloud-active aerosols, Earth-Sci. Rev., 89, 13-41, 2008.

Bauer, H., Kasper-Giebl, A., Zibuschka, F., Hitzenberger, R., Kraus, G. F., and Puxbaum, H.: Determination of the carbon content of airborne fungal spores, Anal. Chem., 74, 91-95, 2002.

Bauer, H., Claeys, M., Vermeylen, R., Schueller, E., Weinke, G., Berger, A., and Puxbaum, H.: Arabitol and mannitol as tracers for the quantification of airborne fungal spores, Atmos. Environ., 42, 588-593, 2008.

Burshtein, N., Lang-Yona, N., and Rudich, Y.: Ergosterol, arabitol and mannitol as tracers for biogenic aerosols in the eastern Mediterranean, Atmos. Chem. Phys., 11, 829-839, doi:10.5194/acp-11-829-2011, 2011.

Cachier, H.: Isotopic characterization of carbonaceous aerosols, Aerosol Sci. Technol., 10, 379-385, 1989.

Cahill, T. M., Seaman, V. Y., Charles, M. J., Holzinger, R., and Goldstein, A. H.: Secondary organic aerosols formed from oxidation of biogenic volatile organic compounds in the Sierra Nevada Mountains of California, J. Geophys. Res.-Atmos., 111, D16312, doi:10.1029/2006JD007178, 2006. 
Claeys, M., Graham, B., Vas, G., Wang, W., Vermeylen, R., Pashynska, V., Cafmeyer, J., Guyon, P., Andreae, M. O., Artaxo, P., and Maenhaut, W.: Formation of secondary organic aerosols through photooxidation of isoprene, Science, 303, 1173-1176, 2004.

Claeys, M., Szmigielski, R., Kourtchev, I., van der Veken, P., Vermeylen, R., Maenhaut, W., Jaoui, M., Kleindienst, T. E., Lewandowski, M., Offenberg, J., and Edney, E. O.: Hydroxydicarboxylic acids: Markers for secondary organic aerosol from the photooxidation of -pinene, Environ. Sci. Technol., 41, 16281634, 2007.

de Gouw, J. and Jimenez, J. L.: Organic aerosols in the Earth's atmosphere, Environ. Sci. Technol., 43, 7614-7618, 2009.

Després, V. R., Huffman, J. A., Burrows, S. M., Hoose, C., Safatov, A. S., Buryak, G., Fröhlich-Nowoisky, J., Elbert, W., Andreae, M. O., Pöschl, U., and Jaenicke, R.: Primary biological aerosol particles in the atmosphere: a review, Tellus B, 64, 15598, doi:10.3402/tellusb.v64i0.15598, 2012.

El Haddad, I., Marchand, N., Temime-Roussel, B., Wortham, H., Piot, C., Besombes, J.-L., Baduel, C., Voisin, D., Armengaud, A., and Jaffrezo, J.-L.: Insights into the secondary fraction of the organic aerosol in a Mediterranean urban area: Marseille, Atmos. Chem. Phys., 11, 2059-2079, doi:10.5194/acp-11-20592011, 2011.

Elbert, W., Taylor, P. E., Andreae, M. O., and Pöschl, U.: Contribution of fungi to primary biogenic aerosols in the atmosphere: wet and dry discharged spores, carbohydrates, and inorganic ions, Atmos. Chem. Phys., 7, 4569-4588, doi:10.5194/acp-7-4569-2007, 2007.

Engling, G., Lee, J. J., Tsai, Y.-W., Lung, S.-C. C., Chou, C. C.K., and Chan, C.-Y.: Size-resolved anhydrosugar composition in smoke aerosol from controlled field burning of rice straw, Aerosol Sci. Technol., 43, 662-672, 2009.

Fabbri, D., Marynowski, L., Fabianska, M. J., Zaton, M., and Simoneit, B. R. T.: Levoglucosan and other cellulose markers in pyrolysis of Miocene lignites-geochemical and environmental implications, Environ. Sci. Technol., 42, 2957-2963, 2008.

Fabbri, D., Torri, C., Simoneit, B. R. T., Marynowski, L., Rushdi, A. I., and Fabianska, M. J.: Levoglucosan and other cellulose and lignin markers in emissions from burning of Miocene lignites, Atmos. Environ., 43, 2286-2295, 2009.

Fröhlich-Nowoisky, J., Burrows, S. M., Xie, Z., Engling, G., Solomon, P. A., Fraser, M. P., Mayol-Bracero, O. L., Artaxo, P., Begerow, D., Conrad, R., Andreae, M. O., Després, V. R., and Pöschl, U.: Biogeography in the air: fungal diversity over land and oceans, Biogeosciences, 9, 1125-1136, doi:10.5194/bg9-1125-2012, 2012.

Fu, P. Q., Kawamura, K., Okuzawa, K., Aggarwal, S. G., Wang, G. H., Kanaya, Y., and Wang, Z. F.: Organic molecular compositions and temporal variations of summertime mountain aerosols over Mt. Tai, North China Plain, J. Geophys. Res.-Atmos, 113, D19107, doi:10.1029/2008JD009900, 2008.

Fu, P. Q., Kawamura, K., and Barrie, L. A.: Photochemical and other sources of organic compounds in the Canadian high Arctic aerosol pollution during winter-spring, Environ. Sci. Technol., 43, 286-292, 2009.

Fu, P. Q., Kawamura, K., Kanaya, Y., and Wang, Z. F.: Contributions of biogenic volatile organic compounds to the formation of secondary organic aerosols over Mt. Tai, Central East China, Atmos. Environ., 44, 4817-4826, 2010.
Fu, P. Q., Kawamura, K., and Miura, K.: Molecular characterization of marine organic aerosols collected during a roundthe-world cruise, J. Geophys. Res.-Atmos., 116, D13302, doi:10.1029/2011JD015604, 2011.

Gamble, D. S., Underdown, A. W., and Landford, C. H.: Copper (II) titration of fulvic acid ligand sites with theoretical, potentiometric, and spectrophotometric analysis, Anal. Chem., 52, 19011908, 1980.

Graham, B., Mayol-Bracero, O. L., Guyon, P., Robert, G. C., Decesari, S., Facchini, M. C., Artaxo, P., Maenhaut, W. P. K., and Andreae, M. O.: Water-soluble organic compounds in biomass burning aerosols over Amazonia: 1. Characterization by NMR and GC-MS, J. Geophys. Res., 107, 8047, doi:10.1029/2001JD000336, 2002.

Graham, B., Guyon, P., Taylor, P. E., Artaxo, P., Maenhaut, W., Glovsky, M. M., Flagan, R. C., and Andreae, M. O.: Organic compounds present in the natural Amazonian aerosol: Characterization by gas chromatography-mass spectrometry, J. Geophys. Res.-Atmos., 108, 4766, doi:10.1029/2003JD003990, 2003.

Hu, D., Bian, Q., Li, T. W. Y., Lau, A. K. H., and Yu, J. Z.: Contributions of isoprene, monoterpenes, -caryophyllene, and toluene to secondary organic aerosols in Hong Kong during the summer of 2006, J. Geophys. Res.-Atmos., 113, D22206, doi:10.1029/2008JD010437, 2008.

Iinuma, Y., Bruggemann, E., Gnauk, T., Muller, K., Andreae, M. O., Helas, G., Parmar, R., and Herrmann, H.: Source characterization of biomass burning particles: The combustion of selected European conifer, African hardwood, savanna grass, and German and Indonesian peat, J. Geophys. Res.-Atmos., 112, D08209, doi:10.1029/2006JD007120, 2007.

Irei, S., Huang, L., Collin, F., Zhang, W., Hastie, D., and Rudolph, J.: Flow reactor studies of the stable carbon isotope composition of secondary particulate organic matter generated by OH-radicalinduced reactions of toluene, Atmos. Environ., 40, 5858-5867, 2006.

Jaoui, M., Lewandowski, M., Kleindienst, T. E., Offenberg, J. H., and Edney, E. O.: $\beta$-Caryophyllinic acid: An atmospheric tracer for $\beta$-caryophyllene secondary organic aerosol, Geophys. Res. Lett., 34, L05816, doi:10.1029/2006GL028827, 2007.

Kanakidou, M., Seinfeld, J. H., Pandis, S. N., Barnes, I., Dentener, F. J., Facchini, M. C., Van Dingenen, R., Ervens, B., Nenes, A., Nielsen, C. J., Swietlicki, E., Putaud, J. P., Balkanski, Y., Fuzzi, S., Horth, J., Moortgat, G. K., Winterhalter, R., Myhre, C. E. L., Tsigaridis, K., Vignati, E., Stephanou, E. G., and Wilson, J.: Organic aerosol and global climate modelling: a review, Atmos. Chem. Phys., 5, 1053-1123, doi:10.5194/acp-5-1053-2005, 2005.

Kawamura, K. and Sakaguchi, F.: Molecular distributions of water soluble dicarboxylic acids in marine aerosols over the Pacific Ocean including tropics, J. Geophys. Res.-Atmos., 104, 35013509, 1999.

Kawamura, K., Ng, L.-L., and Kaplan, I. R.: Determination of organic acids $\left(\mathrm{C}_{1}-\mathrm{C}_{10}\right)$ in the atmosphere, motor exhausts, and engine oils, Environ. Sci. Technol., 19, 1082-1086, 1985.

Kawamura, K., Ishimura, Y., and Yamazaki, K.: Four years' observations of terrestrial lipid class compounds in marine aerosols from the western North Pacific, Global Biogeochem. Cy., 17, 1003, doi:10.1029/2001GB001810, 2003. 
Kawamura, K., Kobayashi, M., Tsubonuma, N., Mochida, M., Watanabe, T., and Lee, M.: Organic and inorganic compositions of marine aerosols from East Asia: Seasonal variations of watersoluble dicarboxylic acids, major ions, total carbon and nitrogen, and stable $\mathrm{C}$ and $\mathrm{N}$ isotopic composition, in: Geochemical Investigations in Earth and Space Science: A Tribute to Isaac R. Kaplan, edited by: Hill, R. J., Leventhal, J., Aizenshtat, Z., Baedecker, M. J., Claypool, G., Eganhouse, R., Goldhaber, M., and Peters, K., The Geochemical Society, Publication No. 9, 2004.

Kleindienst, T. E., Jaoui, M., Lewandowski, M., Offenberg, J. H., Lewis, C. W., Bhave, P. V., and Edney, E. O.: Estimates of the contributions of biogenic and anthropogenic hydrocarbons to secondary organic aerosol at a southeastern US location, Atmos. Environ., 41, 8288-8300, 2007.

Kourtchev, I., Warnke, J., Maenhaut, W., Hoffmann, T., and Claeys, M.: Polar organic marker compounds in $\mathrm{PM}_{2.5}$ aerosol from a mixed forest site in western Germany, Chemosphere, 73, 13081314, 2008.

Kundu, S., Kawamura, K., Andreae, T. W., Hoffer, A., and Andreae, M. O.: Molecular distributions of dicarboxylic acids, ketocarboxylic acids and $\alpha$-dicarbonyls in biomass burning aerosols: implications for photochemical production and degradation in smoke layers, Atmos. Chem. Phys., 10, 2209-2225, doi:10.5194/acp-10-2209-2010, 2010.

Lewis, D. H. and Smith, D. C.: Sugar alcohols (polyols) in fungi and green plants: 1. Distributions, physiology and metabolism, New Phytol., 66, 143-184, 1967.

Li, J., Wang, Z., Akimoto, H., Yamaji, K., Takigawa, M., Pochanart, P., Liu, Y., Tanimoto, H., and Kanaya, Y.: Nearground ozone source attributions and outflow in central eastern China during MTX2006, Atmos. Chem. Phys., 8, 7335-7351, doi:10.5194/acp-8-7335-2008, 2008.

Li, X., Wang, S., Duan, L., Hao, J., Li, C., Chen, Y., and Yang, L.: Particulate and trace gas emissions from open burning of wheat straw and corn stover in China, Environ. Sci. Technol., 41, 60526058, 2007.

Martinelli, L. A., Camargo, P. B., Lara, L. B. L. S., Victoria, R. L., and Artaxo, P.: Stable carbon and nitrogen isotopic composition of bulk aerosol particles in a $\mathrm{C} 4$ plant landscape of southeast Brazil, Atmos. Environ., 36, 2427-2432, 2002.

Mochida, M. and Kawamura, K.: Hygroscopic properties of levoglucosan and related organic compounds characteristic to biomass burning aerosol particles, J. Geophys. Res.-Atmos., 109, D21202, doi:10.1029/2004JD004962, 2004.

Narukawa, M., Kawamura, K., Takeuchi, N., and Nakajima, T.: Distribution of dicarboxylic acids and carbon isotopic compositions in aerosols from 1997 Indonesian forest fires, Geophys. Res. Lett., 26, 3101-3104, 1999.

Narukawa, M., Kawamura, K., Li, S. M., and Bottenheim, J. W.: Stable carbon isotopic rations and ionic composition of the high Arctic aerosols: An increase in ${ }^{13} \mathrm{C}$ values from winter to spring, J. Geophys. Res.-Atmos., 113, D02312, doi:10.1029/2007JD008755, 2008.

Nozière, B., González, N. J. D., Borg-Karlson, A.-K., Pei, Y., Redeby, J. P., Krejci, R., Dommen, J., Prevot, A. S. H., and Anthonsen, T.: Atmospheric chemistry in stereo: A new look at secondary organic aerosols from isoprene, Geophys. Res. Lett., 38, L11807, doi:10.1029/2011GL047323, 2011.
Pavuluri, C. M. and Kawamura, K.: Evidence for 13-carbon enrichment in oxalic acid via iron catalyzed photolysis in aqueous phase, Geophys. Res. Lett., 39, L03802, doi:10.1029/2011GL050398, 2012.

Pavuluri, C. M., Kawamura, K., Swaminathan, T., and Tachibana, E.: Stable carbon isotopic compositions of total carbon, dicarboxylic acids and glyoxylic acid in the tropical Indian aerosols: Implications for sources and photochemical processing of organic aerosols, J. Geophys. Res.-Atmos., 116, D18307, doi:10.1029/2011JD015617, 2011.

Pöschl, U.: Atmospheric aerosols: Composition, transformation, climate and health effects, Angew. Chem. Int. Ed., 44, 75207540, doi:10.1002/anie.200501122, 2005.

Puxbaum, H., Caseiro, A., Sanchez-Ochoa, A., Kasper-Giebl, A., Claeys, M., Gelencser, A., Legrand, M., Preunkert, S., and Pio, C.: Levoglucosan levels at background sites in Europe for assessing the impact of biomass combustion on the European aerosol background, J. Geophys. Res.-Atmos., 112, D23S05, doi:10.1029/2006JD008114, 2007.

Rogge, W. F., Mazurek, M. A., Hildemann, L. M., Cass, G. R., and Simoneit, B. R. T.: Quantification of urban organic aerosols at a molecular level: Identification, abundance and seasonal variation, Atmos. Environ. A-Gen., 27, 1309-1330, 1993.

Rudolph, J., Czuba, E., and Huang, L.: The stable carbon isotope fractionation for reactions of selected hydrocarbons with $\mathrm{OH}-$ radicals and its relavance for atmospheric chemistry, J. Geophys. Res.-Atmos., 105, 29329-29346, 2000.

Sheesley, R. J., Schauer, J. J., Chowdhury, Z., Cass, G. R., and Simoneit, B. R. T.: Characterization of organic aerosols emitted from the combustion of biomass indigenous to South Asia, J. Geophys. Res.-Atmos., 108, 4285, doi:10.1029/2002JD002981, 2003.

Simoneit, B. R. T.: Biomass burning-a review of organic tracers for smoke from incomplete combustion, Appl. Geochem., 17, 129162, 2002.

Simoneit, B. R. T. and Elias, V. O.: Organic tracers from biomass burning in atmospheric particulate matter over the ocean, Mar. Chem., 69, 301-312, 2000.

Simoneit, B. R. T. and Mazurek, M. A.: Organic matter of the troposphere-II. Natural background of biogenic lipid matter in aerosols over the rural western United States, Atmos. Environ., 16, 2139-2159, 1982.

Simoneit, B. R. T., Elias, V. O., Kobayashi, M., Kawamura, K., Rushdi, A. I., Medeiros, P. M., Rogge, W. F., and Didyk, B. M.: Sugars-dominant water-soluble organic compounds in soils and characterization as tracers in atmospheric particulate matter, Environ. Sci. Technol., 38, 5939-5949, 2004a.

Simoneit, B. R. T., Kobayashi, M., Mochida, M., Kawamura, K., Lee, M., Lim, H. J., Turpin, B. J., and Komazaki, Y.: Composition and major sources of organic compounds of aerosol particulate matter sampled during the ACE-Asia campaign, J. Geophys. Res.-Atmos., 109, D19S10, doi:10.1029/2004JD004598, 2004 b.

Smith, B. N. and Epstain, S.: Two catagories of ${ }^{13} \mathrm{C} /{ }^{12} \mathrm{C}$ ratios of higher plants, Plant Physiol., 47, 380-384, 1971.

Staples, C. A., Peterson, D. R., Parkerton, T. F., and Adams, W. J.: The environmental fate of phthalate esters: A literature review, Chemosphere, 35, 667-749, 1997.

Streets, D. G., Yarber, K. F., Woo, J. H., and Carmichael, G. R.: Biomass burning in Asia: Annual and seasonal estimates 
and atmospheric emissions, Global Biogeochem. Cy., 17, 1099, doi:1010.1029/2003GB002040, 2003.

Suh, I., Zhang, R., Molina, L. T., and Molina, M. J.: Oxidation mechanism of aromatic peroxy and bicyclic radicals from $\mathrm{OH}-$ toluene reactions, J. Am. Chem. Soc., 125, 12655-12665, 2003.

Szmigielski, R., Surratt, J. D., Gómez-González, G., Van der Veken, P., Kourtchev, I., Vermeylen, R., Blockhuys, F., Jaoui, M., Kleindienst, T. E., Lewandowski, M., Offenberg, J. H., Edney, E. O., Seinfeld, J. H., Maenhaut, W., and Claeys, M.: 3-Methyl1,2,3-butanetricarboxylic acid: An atmospheric tracer for terpene secondary organic aerosol, Geophys. Res. Lett., 34, L24811, doi:10.1029/2007GL031338, 2007.

Teil, M. J., Blanchard, M., and Chevreuil, M.: Atmospheric fate of phthalate esters in an urban area (Paris-France), Sci. Total Environ., 354, 212-223, 2006.

Tsigaridis, K. and Kanakidou, M.: Global modelling of secondary organic aerosol in the troposphere: a sensitivity analysis, Atmos. Chem. Phys., 3, 1849-1869, doi:10.5194/acp-3-1849-2003, 2003.

Turpin, B. J., Saxena, P., and Andrews, E.: Measuring and simulating particulate organics in the atmosphere: problems and prospects, Atmos. Environ., 34, 2983-3013, 2000.

Uno, I., Amano, H., Emori, S., Kinoshita, K., Matsui, I., and Sugimoto, N.: Trans-Pacific yellow sand transport observed in April 1998: A numerical simulation, J. Geophys. Res., 106, 1833118334, 2001.

van Pinxteren, D. and Herrmann, H.: Determination of functionalised carboxylic acids in atmospheric particles and cloud water using capillary electrophoresis/mass spectrometry, J. Chromatogr. A, 1171, 112-123, 2007.

Wang, G. H., Kawamura, K., Lee, S., Ho, K. F., and Cao, J. J.: Molecular, seasonal, and spatial distributions of organic aerosols from fourteen Chinese cities, Environ. Sci. Technol., 40, 46194625, 2006.

Wang, G. H., Kawamura, K., Umemoto, N., Xie, M. J., Hu, S. Y., and Wang, Z. F.: Water-soluble organic compounds in $\mathrm{PM}_{2.5}$ and size-segregated aerosols over Mount Tai in North China Plain, J. Geophys. Res.-Atmos., 114, D19208, doi:10.1029/2008JD011390, 2009a.

Wang, G. H., Kawamura, K., Xie, M. J., Hu, S. Y., Cao, J. J., An, Z. S., Waston, J. G., and Chow, J. C.: Organic molecular compositions and size distributions of Chinese summer and autumn aerosols from Nanjing: Characteristic haze event caused by wheat straw burning, Environ. Sci. Technol., 43, 6493-6499, $2009 b$

Wang, G. H., Chen, C. L., Li, J. J., Zhou, B. H., Xie, M. J., Hu, S. Y., Kawamura, K., and Chen, Y.: Molecular composition and size distribution of sugars, sugar-alcohols and carboxylic acids in airborne particles during a severe urban haze event caused by wheat straw burning, Atmos. Environ., 45, 2473-2479, 2011.
Wang, H. B. and Kawamura, K.: Stable carbon isotopic composition of low-molecular-weight dicarboxylic acids and ketoacids in remote marine aerosols, J. Geophys. Res.-Atmos., 111, D07304, doi:10.1029/2005JD006466, 2006.

Yamaji, K., Li, J., Uno, I., Kanaya, Y., Irie, H., Takigawa, M., Komazaki, Y., Pochanart, P., Liu, Y., Tanimoto, H., Ohara, T., Yan, X., Wang, Z., and Akimoto, H.: Impact of open crop residual burning on air quality over Central Eastern China during the Mount Tai Experiment 2006 (MTX2006), Atmos. Chem. Phys., 10, 7353-7368, doi:10.5194/acp-10-7353-2010, 2010.

Yang, Y., Chan, C.-Y., Tao, J., Lin, M., Engling, G., Zhang, Z., Zhang, T., and Su, L.: Observation of elevated fungal tracers due to biomass burning in the Sichuan Basin at Chengdu City, China, Sci. Total Environ., 431, 68-77, 2012.

Yttri, K. E., Dye, C., and Kiss, G.: Ambient aerosol concentrations of sugars and sugar-alcohols at four different sites in Norway, Atmos. Chem. Phys., 7, 4267-4279, doi:10.5194/acp-7-4267-2007, 2007.

Yttri, K. E., Simpson, D., Nøjgaard, J. K., Kristensen, K., Genberg, J., Stenström, K., Swietlicki, E., Hillamo, R., Aurela, M., Bauer, H., Offenberg, J. H., Jaoui, M., Dye, C., Eckhardt, S., Burkhart, J. F., Stohl, A., and Glasius, M.: Source apportionment of the summer time carbonaceous aerosol at Nordic rural background sites, Atmos. Chem. Phys., 11, 13339-13357, doi:10.5194/acp11-13339-2011, 2011a.

Yttri, K. E., Simpson, D., Stenström, K., Puxbaum, H., and Svendby, T.: Source apportionment of the carbonaceous aerosol in Norway - quantitative estimates based on ${ }^{14} \mathrm{C}$, thermal-optical and organic tracer analysis, Atmos. Chem. Phys., 11, 9375-9394, doi:10.5194/acp-11-9375-2011, $2011 \mathrm{~b}$.

Zhang, T., Engling, G., Chan, C.-Y., Zhang, Y.-N., Zhang, Z.-S., Lin, M., Sang, X.-F., Li, Y. D., and Li, Y.-S.: Contribution of fungal spores to particulate matter in a tropical rainforest, Environ. Res. Lett., 5, 024010, doi:10.1088/1748-9326/5/2/024010, 2010.

Zhang, X. Y., Wang, Y. Q., Niu, T., Zhang, X. C., Gong, S. L., Zhang, Y. M., and Sun, J. Y.: Atmospheric aerosol compositions in China: spatial/temporal variability, chemical signature, regional haze distribution and comparisons with global aerosols, Atmos. Chem. Phys., 12, 779-799, doi:10.5194/acp12-779-2012, 2012.

Zheng, M., Salmon, L. G., Schauer, J. J., Zeng, L., Kiang, C. S., Zhang, Y., and Cass, G. R.: Seasonal trends in $\mathrm{PM}_{2.5}$ source contributions in Beijing, China, Atmos. Environ., 39, 3967-3976, 2005 . 